Mini-review

\title{
Oleanolic acid and its synthetic derivatives for the prevention and therapy of cancer: Preclinical and clinical evidence
} \author{
Anupam Bishayee $\mathrm{e}^{\mathrm{e} *}$ \\ a Department of Pharmacology, Yong Loo Lin School of Medicine, National University of Singapore, Singapore \\ ${ }^{\mathrm{b}}$ Cancer Science Institute of Singapore, National University of Singapore, Centre for Translational Medicine, Singapore \\ 'School of Biomedical Sciences, Faculty of Health Sciences, Curtin University, Western Australia, Australia \\ ${ }^{\mathrm{d}}$ Department of Biological Sciences, University of North Texas, Denton, TX, USA \\ ${ }^{\mathrm{e}}$ Department of Pharmaceutical Sciences, School of Pharmacy, American University of Health Sciences, Signal Hill, CA, USA
}

Muthu K. Shanmugam ${ }^{a}$, Xiaoyun Dai ${ }^{a}$, Alan Prem Kumar ${ }^{\mathrm{a}, \mathrm{b}, \mathrm{c}, \mathrm{d}}$, Benny K.H. Tan ${ }^{\mathrm{a}}$, Gautam Sethi ${ }^{\mathrm{a}, \mathrm{b}, *}$,

\section{A R T I C L E I N F O}

\section{Article history}

Received 30 November 2013

Received in revised form 6 January 2014

Accepted 20 January 2014

\section{Keywords:}

Oleanolic acid

Synthetic triterpenoids

CDDO

Pentacyclic triterpenoids

Inflammation cancer

\begin{abstract}
A B S T R A C T
Oleanolic acid (OA, 3ß-hydroxyolean-12-en-28-oic acid) is a ubiquitous pentacyclic multifunctional triterpenoid, widely found in several dietary and medicinal plants. Natural and synthetic OA derivatives can modulate multiple signaling pathways including nuclear factor- $\kappa \mathrm{B}, \mathrm{AKT}$, signal transducer and activator of transcription 3, mammalian target of rapamycin, caspases, intercellular adhesion molecule 1 , vascular endothelial growth factor, and poly (ADP-ribose) polymerase in a variety of tumor cells. Importantly, synthetic derivative of OA, 2-cyano-3,12-dioxoolean-1,9-dien-28-oic acid (CDDO), and its C-28 methyl ester (CDDO-Me) and C28 imidazole (CDDO-Im) have demonstrated potent antiangiogenic and antitumor activities in rodent cancer models. These agents are presently under evaluation in phase I studies in cancer patients. This review summarizes the diverse molecular targets of OA and its derivatives and also provides clear evidence on their promising potential in preclinical and clinical situations.
\end{abstract}

(C) 2014 Elsevier Ireland Ltd. All rights reserved.

\section{Introduction}

Triterpenes have existed in nature from ancient times and have been identified in prehistoric geological sediments [1]. Triterpenes are widespread in nature and are highly abundant in medicinal plants especially in the leaves, bark, fruits and seeds of the herbs $[2,3]$. Based on the number of isoprene units, triterpenes can be acyclic, mono-, bi-, tri-, tetra- and pentacyclic. Pentacyclic triterpenes have six isoprene units with a basic formula of $\mathrm{C}_{30} \mathrm{H}_{48}$. They are synthesized in plants by cyclization of squalene. Latest estimate indicates the existence of approximately 20,000 different triterpene saponins from various sources $[1,3,4]$. The most studied triterpenes are the tetracyclic triterpenes, such as cycloartanes, dammaranes, euphanes and protostanes, and pentacyclic

\footnotetext{
* Corresponding authors. Address: Department of Pharmacology, Yong Loo Lin School of Medicine, National University of Singapore, Singapore. Tel.: +65 65163267; fax: +65 68737690 (G. Sethi). Address: Department of Pharmaceutical Sciences, School of Pharmacy, American University of Health Sciences, 1600 East Hill Street, Signal Hill, CA 90755, USA. Tel.: +1 (562) 988 2278x2038; fax: +1 (562) 9881791 (A. Bishayee). ee).

E-mail addresses: phcgs@nus.edu.sg (G. Sethi), abishayee@auhs.edu (A. Bishay-
}

triterpenes, such as gammaceranes, hopanes, lupanes, oleananes and ursanes. In the past decade, numerous publications have indicated the various bioactivities of pentacyclic triterpenoids. Pentacyclic triterpenes in general possess unique biological properties. These bioactivities include antitumor, anti-inflammatory, antiviral, antidiabetic, antimicrobial, antiparasitic, cardioprotective, hepatoprotective, gastroprotective and wound healing effects [5]. The antitumor and anti-inflammatory effects of pentacyclic triterpenoids have received the most attention and a couple of synthetic oleanolic acid derivatives are now in clinical trials [3,4,6-9].

\section{Oleanolic acid}

Oleanolic acid (OA, 3 $\beta$-hydroxyolean-12-en-28-oic acid) (Fig. 1A) is a bioactive pentacyclic triterpenoid belonging to the family Oleaceae and has been isolated from more than 1600 plant species, the majority of them are edible plants and medicinal herbs $[5,10,11]$. OA is abundant in ginseng root [12] and in olive plant (Olea europaea) from which the compound derives its name [13]. The olive plant is the primary commercial source for the compound but other sources include Arctostaphyllos uva-ursi (Bearberry), Calluna vulgaris (Heather), Crataeva nurvala (Three leaved caper) 
A

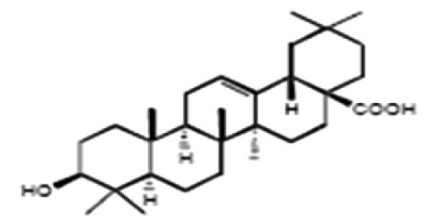

Oleanolic acid

B

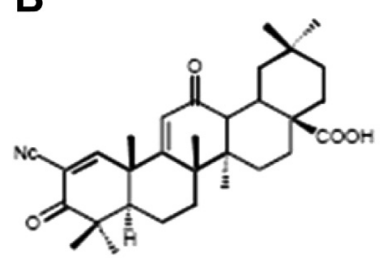

CDDO

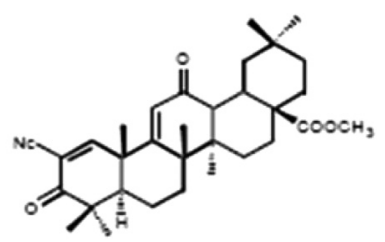

CDDO-Me
Fig. 1. The chemical structures of oleanolic acid and its derivatives. (A) natural oleanolic acid and (B) synthetic oleanane triterpenoids.

Ganoderma lucidum (Reishi), Sambucus chinensis (Chinese elder), Solanum incanum (Sodom's apple). OA occurs in olive leaves as almost pure crystals that prevent fungal attack [14] and function as a defense compound against herbivores or pathogens or as allelopathic agents. OA exists in nature as the free acid, but also serves as an aglycone of triterpenoid saponins linked with one or more sugar moieties to form glycosides [1,4-6]. Often OA and its isomer, ursolic acid (UA) are found in combination and have similar pharmacological properties $[6,7,10,11]$. UA is easily obtained in very high purity by methanol extraction of rosemary leaf while OA can be easily obtained in high yield from olive pulp remaining after crushing of the olive fruit and also from olive leaves $[3,15]$. Thus naturally abundant OA serves as scaffolds for additional modifications to achieve semi-synthetic pentacyclic OA triterpenoids. Among all the triterpenes, pentacyclic OA triterpenoid have been shown to have unique biological activities such as anti-inflammatory, cardio-, hepato-, and gastro-protective, antitumor, antiviral, antidiabetic, antimicrobial, antiparasitic, analgesic and woundhealing effects as well as inducing apoptosis in cancer cells $[5,16]$. Major advancements in triterpenoid research during the current decade have been made in the synthesis of synthetic triterpenoids. For example, the OA derivative, 2-cyano-3, 12-dioxooleana-1,9(11)-dien-28-oic acid (CDDO, Fig. 1B) and its C-28 methyl ester (CDDO-Me or bardoxolone methyl, Fig. 1B) and C28 imidazole (CDDO-Im) demonstrated potent anti-inflammatory and antitumor activities $[17,18]$. In addition to these three derivatives, others such as di-CDDO (nitrile at C17 position of CDDO) and various amides such as CDDO-MA (methyl amide), CDDO-EA (ethyl amide), and CDDO-TFEA (trifluoroethyl amide) were synthesized and tested for their antitumor properties. All these molecules affect multiple intracellular processes such as blocking various pro-inflammatory cytokines and chemokines, repressing tumor cell proliferation and inducing tumor cell apoptosis [16,19-23] (Fig. 2). This review will mainly focus on $\mathrm{OA}$ and its derivatives.

\section{In vitro effects of $\mathrm{OA}$ and its synthetic derivatives on cancer cells}

\subsection{Breast cancer}

The role of triterpenoids in the chemoprevention and therapy of breast cancer has been excellently reviewed previously [24]. OA isolated from Glossogyne tenuifolia showed weak antitumor activity against MCF7 and MDA-MB-231 breast cancer cells [25]. Several investigators confirmed antiproliferative effect of OA against several breast carcinoma cell lines [26,27] (Table 1 ).

A novel synthetic OA derivative, achyranthoside $\mathrm{H}$ methyl ester (AH-Me) exhibited significant cytotoxicity against human breast cancer MCF-7 and MDA-MB-453 cells, with respective $\mathrm{IC}_{50}$ values of 4.0 and $6.5 \mu \mathrm{M}$. AH-Me-induced apoptosis was supported by dose- and time-dependent increases in the sub- $G_{1}$ population and activation of caspase-3 [28]. CDDO was shown to inhibit proliferation and induce peroxisome proliferator-activated receptor- $\gamma$ $($ PPAR- $\gamma$ ) in human epidermal growth factor receptor 2 (HER2) overexpressing breast cancer cells [29,30]. CDDO-Im induced apoptosis in estrogen receptor negative and BRCA1 null breast cancer cells, by inducing reactive oxygen species (ROS), and subsequently DNA damage [31,32]. In another study, CDDO-Im in combination with Gemini vitamin D analog, ABXL0124, potently inhibited HER2 or ErbB2 overexpressing breast cancer cells and repressed downstream signaling proteins, such as pErk1/2, pAKT, cMyc, cyclin D1 and Bcl-2 [33]. CDDO-Im was shown to effectively block EGFR/signal transducer and activator of transcription 3 (STAT3)/Sox-2 signaling pathway in tumor-associated macrophages (TAMs) which are known to promote growth and metastasis of breast cancer [34]. CDDO-Me inhibits the JAK/STAT3 pathway in MDA-MB-468 breast cancer cells [35].

\subsection{Glioma and glioblastoma}

OA $(25 \mu \mathrm{M})$ induced accumulation of ROS in 1321N1 astrocytoma cell line, resulting in apoptosis [36]. One possible mechanism might be that generation of ROS triggers the antioxidant cascade including nuclear factor E2-related factor 2 ( $\mathrm{Nrf} 2$ ) over-expression. In high grade glioma patients, TAMs polarized to the M2 phenotype promote tumor cell proliferation and are always associated with poor prognosis. OA significantly inhibited the proliferation in both U373 human glioblastoma cells and in human macrophages by inhibiting the expression of CD163, IL-10, M2 polarization of macrophages and STAT3 phosphorylation [37].

Glioblastoma and neuroblastoma are primary brain tumors that are unresponsive or weakly responsive to chemotherapeutic agents. CDDO, CDDO-Me and CDDO-Im inhibited the growth of glioblastoma cells (U87MG, U251MG) and neuroblastoma cells (SK-N-MC). CDDO-Me and CDDO-Im showed equipotent anticancer activity, and induced apoptosis in these cell lines [38]. All CDDO analogs such as CDDO-Me, CDDO-Im, CDDO-EA, CDDO-TFEA, and CDDO-DE induced apoptosis by activating mitochondrial proteins and caspase- 3 in 22 pediatric solid tumor cell lines, including neuroblastoma, rhabdomyosarcoma, osteosarcoma, and Ewing's sarcoma [39].

\subsection{Colorectal cancer}

3-O-acetyloleanolic acid induced apoptosis in HCT-116 cells by an extrinsic caspase signaling cascade and by up-regulation of death receptor 5 (DR5) [40].

\subsection{Hepatocellular cancer}

One of the noted effects of OA is its hepatoprotective effect by preventing chemically-induced liver injury and the fibrosis and cirrhosis caused by chronic liver diseases $[10,11,41,42]$. The liver specific chemopreventive and antitumor mechanism of triterpenoids and $\mathrm{OA}$ in particular has recently been reviewed $[43,44]$. OA treatment increased the expression of transcription factor Nrf2, a key transcriptional regulator of antioxidant and detoxifying enzymes $[45,46]$. Nrf2 has been shown to be necessary for the upregulation 


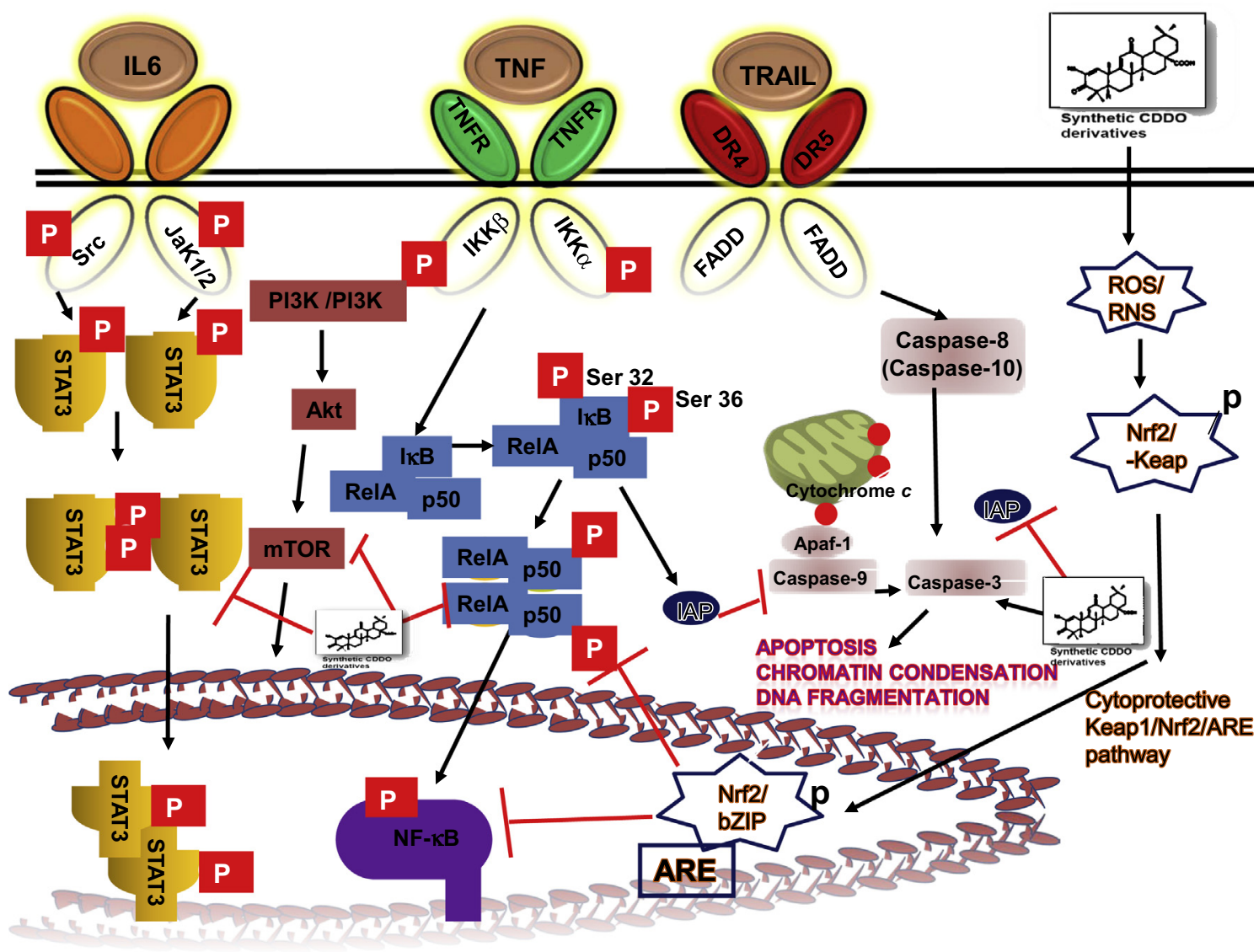

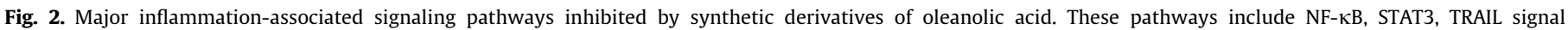
transduction pathways and the Keap1/Nrf2/ARE activation cascade that have been shown to be modulated both in vitro and in vivo.

of genes involved in oxidative stress, such as glutathione S-transferase or superoxide dismutase-containing antioxidant response element (ARE) [47]. In a recent study, it was shown that OA binds to the ligand-binding domain of the farnesoid $X$ receptor (FXR), a ligand-regulated transcription factor that regulates the biosynthesis of bile acid and its excretion from liver cells [48] and modulates the expression of FXR target genes, such as CYP7A1 [49]. Hence a part of Nrf2-mediated hepatoprotective effect of OA may be partly mediated through FXR and by inhibiting NF- $\kappa B$ activation pathway. OA is also reported to have anti-inflammatory and anticancer effects $[8,9]$. OA was found to induce cell cycle arrest by modulating ERK-p53 mediated cell cycle arrest and induced apoptosis in HCC cells via the mitochondrial pathway [50]. OA induced apoptosis by modulating the mitochondrial pathway and down regulating XIAP in HuH7 hepatocellular carcinoma cells [51].

A series of furoxan and glycosyl-based nitric oxide releasing derivatives of $\mathrm{OA}$ have been reported to have potent anticancer activity against HCC cell lines [52-54]. In another series of $\mathrm{O}(2)-$ glycosylated diazeniumdiolate-based derivatives of OA were synthesized and evaluated for their anti-HCC activity. In this series, one particular compound 6 , $\left(\mathrm{O} 2-\beta_{-}{ }^{\mathrm{d}}-\mathrm{G}\right.$-Glactopyranosyl $1-4-[(12-$ en-28- $\beta-^{\mathrm{d}}$-glucopyranosyloleanolate-3-yl-oxy)-succinyl-oxy] piperidin-1-yldiazen-1-ium-1,2-diolate) induced HCC cell apoptosis, characterized by a decrease in mitochondrial membrane potentials and Bcl-2 expression, with greater cytochrome $c$ release, Bax, caspase- 3 and -9 expression in HCC cells [55,56]. Mallavadhani et al. [57] synthesized a series of 17 OA C-17 ester chains consisting of olefinic, acetoacetyl, and bromoalkyl compounds and tested for its antiproliferative activity against SiHa and HeLa (cervix), A-549 (lung), and IMR-32 (neuroblastoma) cancer cell lines. However, all these compounds showed similar activity as their parent compound [57]. OA with azaheterocyclic groups at the 2, 3 position of the A-ring was shown to have cytotoxic activity against HCC line, BEL-7404 cells and induced apoptosis through down-regulation of Bcl-2 and mitochondrial membrane potential, releasing cytochrome $c$, and upregulation of Bax and caspase-3 [58]. A novel PABA/NO derivative of OA was shown to have significant and selective activity against HepG2 cells and induced apoptosis by modulating ROS/MAPK-mediated mitochondrial pathway [59]. OA derivative, with 1-en-2-cyano-3-oxo in ring $A$ and a nitro group at $\mathrm{C}-17$, was shown to be important for its cytotoxicity against HepG2 and Col-02 cells [60]. In the liver, most of the synthetic CDDO analogs also protect against toxic insults such as acetaminophen, aflatoxin, concanavalin A, or cisplatin and against injury from ischemia by up-regulating the Nrf2/ARE pathway [16,20].

\subsection{Hematological malignancies}

OA $(80 \mu \mathrm{M})$ induced apoptosis in HL60 cells via activation of caspase- 9 and caspase- 3 and induced cleavage of poly(ADP-ribose) polymerase [61].

Synthetic OA derivatives inhibited proliferation and induced apoptosis in vitro in a wide variety of human tumor cells including leukemia cells. Olean-12-Eno[2,3-c] [1,2,5] oxadiazol-28-oic acid (OEOA), synthetic derivative of $\mathrm{OA}$, induced $\mathrm{G}_{1}$ cell cycle arrest as well as differentiation in human leukemia cell lines, K562, HEL and JURKAT [62]. Three new active oleanolic vinyl bornates inhibited the growth of leukemia cells (Jurkat and K562) and Burkitt's lymphoma cells (Jijoye) without concomitant inhibition of non-tumoral human fibroblasts [63]. CDDO primarily activated the 
Table 1

In vitro anticancer effects of natural and synthetic oleanolic acid.

\begin{tabular}{|c|c|c|}
\hline Molecules & Biological effects & References \\
\hline \multicolumn{3}{|l|}{ Breast cancer } \\
\hline $\mathrm{OA}$ & Inhibits proliferation of human breast cancer cell lines MCF-7 and MDA-MB-231 & {$[26]$} \\
\hline $\mathrm{OA}$ & Induces apoptosis in MCF7, T47D, SKBR3 cells and in tomoxifen resistant MCF7 cells & [27] \\
\hline $\mathrm{AH}-\mathrm{Me}$ & Induces apoptosis in MCF7 and MDA-MB 435 cells & {$[28]$} \\
\hline CDDO & Inhibits proliferation and induce PPAR $\gamma$ in HER2 overexpressing cells & {$[29,30]$} \\
\hline CDDO-Me & Inhibits JAK/STAT pathway in MDA-MB-468 cells & [35] \\
\hline CDDO-Im & $\begin{array}{l}\text { Induces apoptosis in estrogen receptor negative and in BRCA1 null cells; Inhibits EGFR/STAT3/Sox-2 } \\
\text { pathway }\end{array}$ & {$[31-34]$} \\
\hline \multicolumn{3}{|c|}{ 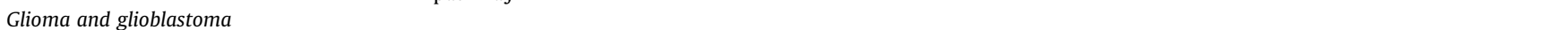 } \\
\hline \multirow[t]{2}{*}{$\mathrm{OA}$} & Induces apoptosis of astrocytoma cells & [36] \\
\hline & Inhibits proliferation of U373 glioblastoma cells and suppresses STAT3 phosphorylation & [37] \\
\hline CDDO; CDDO-Me; CDDO-Im & Inhibits proliferation of glioblastoma cells U87MG and U251MG and neuroblastoma cells (SK-N-MC) & [38] \\
\hline All CDDO analogs & Induces apoptosis in 22 pediatric solid tumor cells & [39] \\
\hline \multicolumn{3}{|l|}{ Hepatocellular cancer } \\
\hline $\mathrm{OA}$ & Activates Keap1-Nrf1-ARE pathway; Exhibits hepatoprotective and chemopreventive effects & {$[16,20,41-44]$} \\
\hline $\begin{array}{l}\text { Furoxan- and glycosyl- based NO releasing } \\
\text { OA }\end{array}$ & Induces apoptosis in HCC cells & {$[50-52]$} \\
\hline $\mathrm{O}(2)$-glycosylated diazeniumdiolate-OA & Decreases mitochondrial membrane potential and induces apoptosis in HCC cells & {$[55,56]$} \\
\hline Azaheterocyclic-OA & Exerts cytotoxic activity in BEL-7404 cell line & [58] \\
\hline $\mathrm{PABA} / \mathrm{NO}-\mathrm{OA}$ & Modulates ROS/MAPK pathway & [59] \\
\hline \multicolumn{3}{|l|}{ Leukemia and lymphoma } \\
\hline OEOA & Induces $\mathrm{G}_{1}$ cell cycle arrest and differentiation in K562 HEL and JURKAT cells & [62] \\
\hline OA vinyl boronates & Inhibits proliferation of JURKAT, K562 and Jijoye cells & [63] \\
\hline CDDO; CDDO-Me; CDDO-Im & $\begin{array}{l}\text { Induces apoptosis in myeloid leukemia cells, pediatric acute lymphoblastic leukemia, MOLT-4, chronic } \\
\text { lymphocytic leukemia, U937, HL-60, in diffuse large B-cell lymphoma cells; } \\
\text { Inhibits NF- } \kappa \text { B activation in U-937 cells and induces autophagy in imatinib resistant chronic } \\
\text { myelogenous leukemia cells }\end{array}$ & {$[64-68,74]$} \\
\hline \multicolumn{3}{|l|}{ Lung cancer } \\
\hline $\mathrm{OA}$ & Induces apoptosis of normal and multidrug resistant non-small cell lung cancer cell line & [77] \\
\hline CDDO-Me & Induces apoptosis by modulation of mitochondrial membrane potential in lung cancer cells & [79-81] \\
\hline \multicolumn{3}{|l|}{ Ovarian cancer } \\
\hline CDDO & $\begin{array}{l}\text { Inhibits proliferation of 2774, SKOV3, CAOV3, OVCAR3, NMP-1, HEY, } 2008 \text { and 2008.C13 ovarian cancer } \\
\text { cells }\end{array}$ & [82] \\
\hline CDDO-Im & $\begin{array}{l}\text { Induces apoptosis and inhibits JAK/STAT activation in normal 2780, SKOV3, OVCAR3, HEY and multidrug } \\
\text { resistant variants }\end{array}$ & [9] \\
\hline CDDO-Me & $\begin{array}{l}\text { Inhibits IL-6 secretion, STAT3-regulated gene products in paclitaxel and cisplatin resistant cells and in } \\
\text { OVCAR-5 and MDAH2774 cells }\end{array}$ & [83-85] \\
\hline \multicolumn{3}{|l|}{ Osteosarcoma cancer } \\
\hline Dextrose-OA & Induces apoptosis in MG-63, U2-OS, HOS and LM8 cells & {$[86]$} \\
\hline \multicolumn{3}{|l|}{ Pancreatic cancer } \\
\hline $\mathrm{OA}$ & Combination with 5-fluorouracil exhibits synergistic cytotoxic effect in Panc-28 cells & {$[88]$} \\
\hline CDDO-Me & $\begin{array}{l}\text { Inhibits NF- } \kappa \mathrm{B} \text { in MiaPaCa- } 2 \text { and Panc1 cells; Inhibits IL6 secretion and STAT3 phosphorylation in } \\
\text { transgenic pancreatic cancer cells }\end{array}$ & [89-91] \\
\hline CDDO-Im & Induces apoptosis by modulating mitochondrial glutathione & [92] \\
\hline $\begin{array}{l}\text { Oleanane imidazole carbamates; } \mathrm{N} \text { - } \\
\text { acylimidazoles; N-alkylimidazoles }\end{array}$ & Inhibits proliferation in AsPC- 1 cells & [94] \\
\hline \multicolumn{3}{|l|}{ Prostate cancer } \\
\hline CDDO-Me; CDDO-Im & Increases DR4 and DR5 expression; Inhibits the growth of LNCaP, ALVA31, PC3 and PPC1 cells & {$[95-97,99]$} \\
\hline \multicolumn{3}{|l|}{ Skin cancer } \\
\hline $\mathrm{OA}$ & Induces apoptosis of B16F2 melanoma cells & {$[101]$} \\
\hline CDDO & Increases cytoplasmic fee calcium and induces apoptosis of COLO16 cells & [103] \\
\hline CDDO-Im & $\begin{array}{l}\text { Induces apoptosis of melphalan, dexamethasone and doxorubicin resistant cells; Inhibits STAT3 } \\
\text { phosphorylation }\end{array}$ & {$[104,105]$} \\
\hline
\end{tabular}

extrinsic apoptotic pathway in myeloid leukemia cells [64]. In another study, CDDO, CDDO-Me and CDDO-Im suppressed the growth of pediatric acute lymphoblastic leukemia. The observed cytotoxicity was independent of induced ceramide synthesis in MOLT-4 cells [65]. CDDO and CDDO-Im also displayed antitumor activity against chronic lymphocytic leukemia (CLL) derived from patients and in a mouse model of CLL and small B cell lymphoma (SBL). In in vitro studies, these triterpenoids induced apoptosis of CLL cells [66]. When CDDO was compared to several PPAR- $\gamma$ ligands, including BRL49653 (rosiglitazone) and 15-deoxy-Delta 12,14-prostaglandin J(2), in leukemia (U937 and HL-60) and lymphoid cells (Su-DHL, Sup-M2, Ramos, Raji, Hodgkin's cells, and primary CLL), CDDO-induced differentiation and apoptosis was of greater potency when compared to PPAR- $\gamma$ ligand-induced apoptosis, and it was characterized by loss of mitochondrial membrane potential and caspase activation [67]. Similar results were reported in human diffuse large B-cell lymphoma (DLBCL) [68]. In another study, Lon protease inhibition was shown to mediate CDDO-induced B-lymphoid cell apoptosis, a novel anticancer drug target [69]. Shishodia et al. [70] reported that CDDO-Me inhibited human leukemia cell proliferation, inhibited constitutive and inducible $\mathrm{NF}-\kappa \mathrm{B}$ activation, and NF- $\kappa \mathrm{B}-$ regulated gene products, such as vascular endothelial growth factor (VEGF), cyclooxygenase-2 (COX-2), and matrix metalloproteinase-9. In human U-937 myeloid leukemia cells, CDDO and CDDO-Me directly blocked IKK- $\beta$ activity and thereby the NF- $\kappa B$ pathway by interacting with Cys-179 in 
the IKK- $\beta$ activation loop [71]. Many reported studies showed that CDDO-Me and CDDO-Im are equipotent compared to CDDO, which has lower activity. The combination of CDDO-Me with 5-fluorouracil or paclitaxel, or doxorubicin showed synergistic activity in leukemia [70] and in combination with midostaurin (PKC412, an Fmslike tyrosine kinase-3 inhibitor in clinical trials) CDDO-Me was effective in AML blast cells [72]. Aberrations in many intrinsic signaling pathways contribute to chemoresitant leukemia. In Bcl-xL overexpressing leukemia cells (an intrinsic inhibitor of apoptosis), CDDO-Me did not disrupt mitochondrial transmembrane potential but CDDO-Im induced apoptosis by activating the mitochondrial pathway [73]. CDDO-Me induced autophagy in imatinib-resistant chronic myelogenous leukemia cells by increasing ROS, depleting glutathione and thus disrupting mitochondrial function [74]. In contrast, CDDO-Im induced a transient phosphorylation of Akt in U937 leukemia cells [75].

\subsection{Lung cancer}

OA inhibited the growth of non-small cell lung cancer cell lines (NSCLC), such as A549 and H460, and their multidrug resistant variants, which expressed multidrug resistant protein 1 and $A B C C 1$ protein. OA also induced apoptosis and decreased VEGF expression in NSCLC as well as variety of multidrug resistant cancer cells $[76,77]$. OA treatment in conjunction with radiation has been shown to inhibit cellular glutathione with simultaneous reduction in gamma-glutamylcysteine synthase activity in C6 rat glioma and human A549 lung cancer cells. The combined treatment also caused a drastic decrease in the clonogenic growth of tumor cells [78].

CDDO-Me induced cytochrome $c$ release from the mitochondria leading to apoptosis in a variety of cancer cells, such as U937, HL60, Jurkat T, HCT116, HCT116-Bax-/- and OCI-AML3 cells [79]. In several lung tumor cells, CDDO-Me was shown to induce apoptosis by rapidly down-regulating expression of FLICE-like inhibitory protein (FLIP), an endogenous antagonist of caspase-8 [80], or by activating JNK and C/EBP homologous protein transcription factor (CHOP), thus inducing expression of DR5 and activation of caspase-8 [81].

\subsection{Ovarian cancer}

CDDO inhibited proliferation of a number of epithelial ovarian cancer cell lines, namely 2774, SKOV3, CAOV3, OVCAR3, NMP-1, HEY, 2008 and 2008.C13 [82]. CDDO-Im was also shown to inhibit the proliferation of 2780 ovarian cancer cell line and its chemoresistant derivatives, A2780/ADR and A2780/CISP, OVCAR3, SKOV3 and HEY cancer cell lines and primary ovarian cancer cells and induced apoptosis by inhibiting the JAK/STAT3 pathway [9]. CDDOMe significantly inhibited interleukin-6 (IL-6) secretion in paclitaxel (OVCAR8(TR))- and cisplatin (A2780cp70))-resistant ovarian cancer cell line, repressed Src, Jak2 and STAT3 phosphorylation, induced apoptosis by modulating STAT3-regulated genes, BCL-xL, survivin and Mcl1 [83]. Gao et al. [84,85] demonstrated that CDDO-Me induced ROS generation in OVCAR-5 and MDAH 2774 ovarian cancer cells and inhibited the expression of p-AKT, pmTOR, NF- $\kappa$ Bp65 and NF- $\kappa B$-regulated antiapoptotic proteins Bcl-2, Bcl-xL, C-IAP1 and survivin.

\subsection{Osteosarcoma}

Hua et al. [86] showed that dextrose-linked OA potently inhibited the proliferation and induced apoptosis in MG-63, U2-OS, HOS and LM8 osteosarcoma cells.

\subsection{Pancreatic cancer}

OA inhibited cell proliferation and induced apoptosis via ROSmediated mitochondrial mechanism in pancreatic cancer Panc-28 cells [87]. In an earlier study, OA was shown to potentiate 5-fluorouracil-induced cytotoxicity and also induced apoptosis of human pancreatic cancer cells, Panc-28 [88].

In pancreatic cancer cell lines, MiaPaCa-2 and Panc-1, treatment with CDDO-me induced production of ROS, hydrogen peroxide and superoxide anions and inhibited telomerase activity and also downregulated p-Akt, p-mTOR, NF- $\mathrm{Bp} 65$ and human telomerase reverse transcriptase (hTERT) [89-92]. Using transgenic pancreatic cancer cell lines derived from LSL-Kras ${ }^{\mathrm{G} 12 \mathrm{D} /+}$, LSL-Trp53 $3^{\mathrm{R} 127 \mathrm{H} /+}$, and Pdx-1-Cre (KPC) tumors, CDDO derivatives inhibited STAT3 and IKK activity and blocked constitutive IL- 6 secretion, STAT3 and IKK phosphorylation [23]. In another study, CDDO-Me stimulated the production of ROS thereby increasing levels of the ZBTB10 protein repressor and suppressing the expression of cell cycle regulating proteins, and angiogenic proteins in pancreatic cancer cells [93]. A series of novel oleanane imidazole carbamates, $\mathrm{N}$-acylimidazoles or $\mathrm{N}$-alkylimidazoles showed potent antiproliferative activity in AsPC-1 pancreatic cancer cells [94].

\subsection{Prostate cancer}

CDDO-Me- and CDDO-Im -induced inhibition of growth of LNCaP, ALVA31, Du145, PC3, and PPC1 prostate cancer cells lines were associated with increased expression of DR4 and DR5, which act as cell surface receptors for TRAIL [95]. Treatment with CDDOMe inhibited LNCaP and PC3 prostate cancer cell proliferation and induced apoptosis, which was associated with suppression of hTERT gene expression and inhibition of Akt/NF- $\mathrm{KB} / \mathrm{mTOR}$ pathway [96,97]. Hao et al. [98] described the antitumor activity of 12 derivatives of $\mathrm{OA}$ which exhibited the most potent cytotoxicity against PC3 cancer cells. Deeb et al. [99] show that CDDO-me inhibited hormone-refractory $\mathrm{PC}-3\left(\mathrm{AR}^{-}\right)$and $\mathrm{C} 4-2\left(\mathrm{AR}^{+}\right)$prostate cancer growth and progression by modulating p-Akt, p-mTOR, and NF- $\kappa B$ signaling proteins and their downstream targets, such as p-Bad and p-Foxo3a (for Akt), p-S6K1, p-eIF-4E and p-4E-BP1 (for mTOR), and COX-2, VEGF and cyclin D1 (for NF-kappaB) both in vitro and in vivo. In yet another study, CDDO-M induced ROS in LNCaP and PC3 cells from both non-mitochondrial and mitochondrial sources and induced apoptosis in these cells [100].

\subsection{Skin cancer}

OA ( $\mathrm{IC}_{50}$ of $4.8 \mu \mathrm{M}$ ) exhibited significant cytotoxicity as well as inhibited the growth of B16 2F2 mouse melanoma cells and induced apoptosis in these cells [101]. The effect of chemical modifications of the sugar moiety attached to the aglycone of OA on tumor cell growth recently was reported by Liu et al. [102]. Both OA saponin and its synthetic saponins showed potent cytotoxic activity against human melanoma cancer (A375) [102].

Synthetic OA derivatives are potent inhibitors of cancer cell proliferation and inducers of apoptosis in a variety of tumor cells obtained from various organs. CDDO promoted apoptosis of COLO 16 human skin cancer cells in a dose- and time-dependent manner with concomitant rise in cytoplasmic free $\mathrm{Ca}^{2+}$ [103]. In multidrug resistant multiple myeloma cells which are resistant to melphalan (LR-5), doxorubicin and dexamethasone, CDDO and CDDO-Im-induced apoptosis was associated with loss of mitochondrial membrane potential, superoxide generation, release of mitochondrial protein (cytochrome $c$ ) and activation of caspase- 8 and caspase- 9 and the executioner caspase-3 [19,104], inhibition of STAT3 transcription factor and induction of the expression of endogenous STAT3 inhibitor SHP1 and induction of apoptosis [105]. In another 
recent study, it was demonstrated that CDDO-Im and CDDO-Me can protect human keratinocytes against toxicity from the sulfur mustard analog, 2-chloroethyl ethyl sulfide, by inducing the synthesis of glutathione, which is depleted by sulfur mustard [106].

\section{In vivo antitumor activity of $\mathrm{OA}$ and its synthetic derivatives}

In several reports, OA displayed potent in vitro inhibitory activity against tumor cell proliferation and also powerful induction of apoptosis. However, to determine the in vivo bioactivity, OA was tested in several rodent models of organ-specific cancer (Table 2).

\subsection{Hepatocellular carcinoma}

In a liver cancer model, OA inhibited HCC tumors in Balb/C mice [50]. In this study, mice were randomly divided into three groups: control, low dose of OA and high dose of OA. In OA-treated groups, mice were administered with 75 or $150 \mathrm{mg} / \mathrm{kg}$ /day OA intraperitoneally respectively for 3 weeks. OA significantly inhibited the growth of HCC tumors [50]. Intraperitoneal administration of OA showed a $\mathrm{LD}_{50}$ of $1500 \mathrm{mg} / \mathrm{ml}$ in mice and a single subcutaneous dose of $1000 \mathrm{mg} / \mathrm{ml}$ caused no toxic effects in rats [107].

Synthetic OA derivatives have been used to treat established tumors in experimental animal models. Furoxan- and glycosyl-based nitric oxide releasing OA derivatives displayed low acute toxicity in mice while significantly inhibiting the growth of HCC tumors in vivo [53,54]. A series of $\mathrm{O}(2)$-glycosylated diazeniumdiolatebased OA derivatives were tested for their anti-HCC activity. Compound 6 in this series exhibited low acute toxicity $\left(\mathrm{LD}_{50}=173.3\right.$ $\mathrm{mg} / \mathrm{kg}$ ) and potently inhibited HCC tumor growth in mice (3 mg/ $\mathrm{kg}$, iv) [55]. A novel PABA/NO OA derivative showed potent antitumor activity and significantly reduced tumor volume and tumor weight in a H22 solid tumor model [59]. CDDO-Im when administered for 8 weeks was shown to reduce metastasized tumor burden in the liver after intravenous inoculation of tumor cells [108]. In addition, short-and long-term clinical trials using OA for acute and chronic hepatitis, respectively, demonstrated the safety of this compound [10].

\subsection{Breast carcinoma}

A novel synthetic oleanane triterpenoid (methyl-25-hydroxy-3oxoolean-12-en-28-oate, AMR-Me) when administered orally at doses of $0.8,1.2$ or $1.6 \mathrm{mg} / \mathrm{kg}$, three times a week for eighteen weeks inhibited the growth of 7,12-dimethylbenz(a)antracene (DMBA)-initiated mammary carcinoma in rats [109]. AMR-Me downregulated the expression of estrogen receptor- $\alpha$ (ER- $\alpha$ ), ER$\beta$ and cyclin D1 and diminished Wnt/ $\beta$-catenin signaling during DMBA mammary tumorigenesis in rats [110]. Very recently, it has been shown that AMR-Me downregulated the expression of COX-2 and heat shock protein 90 (HSP90), suppressed the degradation of inhibitory $\kappa \mathrm{B}-\alpha(\mathrm{I} \kappa \mathrm{B}-\alpha)$ and reduced the translocation of NF- $\kappa B$ from cytosol to nucleus in DMBA-induced mammary tumors in rats [111].

In female $\mathrm{BALB} / \mathrm{c}$ or $\mathrm{FVB} / \mathrm{NJ}$ mice orthotopically implanted with breast tumor cells (4TO7 or MMTVB-neu), CDDO-Im formulated as nanoparticles when combined with HER-2 DNA vaccine produced significant antitumor activity and was associated with parallel reduction in the production of pro-inflammatory cytokines such as transforming growth factor- $\beta$, IL- 6 and IL-10 and enhanced tumor-specific cytotoxic T-lymphocyte response [112]. When fed with CDDO-Me mixed with diet beginning at 10 weeks of age, significantly delayed mammary tumor growth by over 3 months in a mouse transgenic model with overexpressing MMTV-neu (ErbB2/ HER2) receptor tyrosine kinase [113]. In another breast cancer mouse model with deletion of BRCA1 gene and a single allele mutation in p53 tumor suppressor, CDDO-Me diet increased lifespan of mice by 5 weeks compared to control mice [114] and induced tumor growth arrest in MDA-MB-435 ER, MDA-MB-468 ER and MCF7 ER xenograft breast cancer mouse models $[29,112,115]$. Intraperitoneal injection of CDDO-Me nanoparticles shown to inhibit invasion and metastasis to lungs in a spontaneously developing mammary tumor derived from chemoresistant 4T1 breast cancer cells subcutaneously implanted in Balb/c mice [30]. In a recent report, potent chemopreventive activity was observed when CDDO-Im was administered orally in combination with BXL0124 (Gemini vitamin D analog) in MMTV-ErbB2/neu mice [33]. In another model of ER-negative breast cancer in MMTV- polyoma middle $\mathrm{T}$ (PyMT) mice fed with CDDO-Me ( $50 \mathrm{mg} / \mathrm{kg}$ diet) at starting 4 weeks of age, CDDO-Me significantly increased the overall survival by 5.2 weeks [116].

\subsection{Colon carcinoma}

Chemopreventive activity of OA was observed in rats subjected to chemical carcinogenesis. Oral treatment of rats with OA $(25 \mathrm{mg} /$ $\mathrm{kg}$ body weight) prevented 1,2-dimethylhydrazine-induced colon carcinoma $[117,118]$.

\subsection{Prostate carcinoma}

CDDO and CDDO-Me prevented the progression of prostate cancer in the TRAMP mice model [119]. In addition, inhibition of progression of pre-neoplastic lesions (i.e., low and high-grade prostate intraepithelial neoplasms) to adenocarcinoma of the prostate by CDDO-Me in TRAMP mice was associated with significant decrease in TERT and its regulatory proteins in the prostate gland. These data provide evidence that telomerase is a potential target of CDDO-Me for the prevention and treatment of prostate cancer [96,97].

\subsection{Leukemia and lymphoma}

Leukemia cells seem to be especially sensitive to triterpenoids. Liposome-formulated CDDO or CDDO-Im triterpenoids reduced leukemia and lymphoma growth in vivo in a TRAF2DN/Bcl-2 transgenic mouse model of chronic lymphocytic leukemia and small Bcell lymphoma. CDDO-Im was more potent than CDDO and induced apoptosis of circulating B cells by 60 to $90 \%$ [66]. In another study, CDDO-Im was shown to be more potent than CDDO in both B16 mice melanoma tumors in BDF1 mice and L1210 murine leukemia. CDDO-Im was injected intraperitonially twice a day for 7 days, at doses of 50, 100, and $200 \mathrm{mg} / \mathrm{kg}$. CDDO-Im induced significant dose-dependent decrease in tumor burden [120]. Combination of all-trans retinoic acid and CDDO-Me significantly improved survival in a syngeneic mouse model of acute promyelocytic leukemia [121].

\subsection{Melanoma}

OA was shown to inhibit mouse skin tumor promotion by $12-\mathrm{O}-$ tetradecanoylphorbol-13-acetate (TPA) [122]. Furthermore, OA decreased the development of melanoma-induced lung metastasis [76]. OA when administered at doses of 5 or $10 \mathrm{mg} / \mathrm{kg} /$ day decreased pulmonary metastasis on day 18 in groups of mice injected intravenously with B16F10 melanoma cells [76].

In SKH1 hairless mice, Di-CDDO (10 nM, twice/week for 17 weeks) applied topically to the skin of mice significantly decreased the incidence of skin tumors induced by chronic low-level UBV radiation [123]. 
Table 2

In vivo antitumor activities of natural and synthetic oleanolic acid.

\begin{tabular}{|c|c|c|c|}
\hline Molecules & Tumor model & Dose & References \\
\hline \multirow[t]{4}{*}{$\mathrm{OA}$} & Inhibits TPA-induced skin tumors in mice & $\begin{array}{l}2.5,5 \text { or } 10 \mu \mathrm{mol} / 0.2 \mathrm{ml} / \mathrm{mouse} ; 30 \mathrm{~min} \\
\text { pretreatment }\end{array}$ & {$[122]$} \\
\hline & Inhibits HCC tumors in Balb/c mice & 75 or $150 \mathrm{mg} /$ day, i.p.; 3 weeks & {$[50]$} \\
\hline & Inhibits 1,2-dimethyhydrazine induced colon carcinoma in rats & $25 \mathrm{mg} / \mathrm{kg}$, oral; 4 weeks & [117] \\
\hline & Inhibits melanoma-induced lung metastasis & $5 \mathrm{mg} / \mathrm{kg} /$ day or $10 \mathrm{mg} / \mathrm{kg} /$ day, i.v.; 18 days & [76] \\
\hline CDDO & $\begin{array}{l}\text { Inhibits leukemia and lymphoma growth in TRAF2DN/Bcl2 transgenic } \\
\text { model of CLL and SBL }\end{array}$ & $\begin{array}{l}5,10 \text { or } 20 \mathrm{mg} / \mathrm{kg} \text {, nine administrations; } 21 \text { - } \\
25 \text { days }\end{array}$ & {$[66]$} \\
\hline \multirow[t]{9}{*}{ CDDO-Me } & $\begin{array}{l}\text { Inhibits breast cancer growth in a MMTV-neu (ErbB2/HER2) transgenic } \\
\text { mouse model }\end{array}$ & 60 or $100 \mathrm{mg} / \mathrm{kg}$, diet; 45 weeks & [113] \\
\hline & Inhibits breast cancer growth in BRCA1 null mice model & $50 \mathrm{mg} / \mathrm{kg}$, diet; $18-24$ weeks & {$[114]$} \\
\hline & $\begin{array}{l}\text { Inhibits MDA-MB- } 435 \text { ER, MDA-MB- } 468 \text { ER and MCF7 ER xenografts in } \\
\text { mice }\end{array}$ & $\begin{array}{l}20 \mathrm{mg} / \mathrm{kg} / \mathrm{mouse} / \text { day, i.v., thrice weekly; } \\
3 \text { weeks }\end{array}$ & {$[29,112,115]$} \\
\hline & Inhibits ER-negative breast cancer in PyMT mice & $50 \mathrm{mg} / \mathrm{kg}$, diet; various time points & {$[116]$} \\
\hline & $\begin{array}{l}\text { Inhibits the progression of prostate cancer in transgenic TRAMP mice } \\
\text { model }\end{array}$ & $7.5 \mathrm{mg} / \mathrm{kg}$, oral, 5 days/week; 20 weeks & [119] \\
\hline & $\begin{array}{l}\text { Significantly improves survival in a syngenic acute promyelocytic } \\
\text { leukemia mice model }\end{array}$ & $5 \mathrm{mg} / \mathrm{kg} ; 2$ day intervals for 23 days & {$[121]$} \\
\hline & Inhibits pancreatic tumor growth in a xenograft mouse model & $7.5 \mathrm{mg} / \mathrm{kg} / \mathrm{day}$, oral; 4 weeks & {$[93]$} \\
\hline & $\begin{array}{l}\text { Inhibits pancreatic tumor growth in a transgenic mouse model of } \\
\text { pancreatic cancer }\end{array}$ & $60 \mathrm{mg} / \mathrm{kg}$, diet; variable time points & [23] \\
\hline & Inhibits lung carcinogenesis in $\mathrm{A} / \mathrm{J}$ mouse model & $\begin{array}{l}\text { CDDO-Me } 60 \mathrm{mg} / \mathrm{kg} \text {, diet; CDDO-EA } 400 \mathrm{mg} / \\
\mathrm{kg} \text {, diet; } 15 \text { weeks }\end{array}$ & {$[21,124]$} \\
\hline CDDO-Me nanoparticles & $\begin{array}{l}\text { Inhibits subcutaneously implanted } 4 \mathrm{~T} 1 \text { breast cancer growth in Balb/c } \\
\text { mice }\end{array}$ & 2 days interval, 5 injections & {$[30]$} \\
\hline \multirow[t]{3}{*}{ CDDO-Im } & $\begin{array}{l}\text { Inhibits hepatocellular carcinoma and reduces metastatic tumor } \\
\text { burden }\end{array}$ & $800 \mathrm{mg} / \mathrm{kg}$, diet; 5 days/week for 56 days & {$[33,108]$} \\
\hline & $\begin{array}{l}\text { Exerts chemopreventive effect when administered in combination } \\
\text { with BXL0124 to MMTV-ErbB2/neu mice }\end{array}$ & $\begin{array}{l}\text { BXL0124 }(0.3 \mu \mathrm{g} / \mathrm{kg}), \text { oral, for } 56 \text { weeks; } \\
(3 \mu \mathrm{mol} / \mathrm{kg}) ; 6 \text { times/week for } 3 \text { weeks }\end{array}$ & [33] \\
\hline & Inhibits melanoma tumors in BDF1 mice and L1201 murine leukemia & $\begin{array}{l}50,100 \text { or } 200 \mathrm{mg} / \mathrm{kg} \text {, i.p.; twice a day for } \\
7 \text { days }\end{array}$ & {$[120]$} \\
\hline \multirow[t]{2}{*}{ CDDO-Im nanoparticles } & $\begin{array}{l}\text { Inhibits orthotopically implanted breast tumor cells ( } 4 \mathrm{TO} 7 \text { or MMTVB- } \\
\text { neu) in female Balb/c nude mice or FVB/NJ mice }\end{array}$ & $\begin{array}{l}200 \mathrm{ml} \text { PBS }\left(1.36 \times 10^{13} \text { particles }\right) \text {, i.v.; } 8 \text { Times } \\
\text { in } 46 \text { days }\end{array}$ & {$[112]$} \\
\hline & $\begin{array}{l}\text { Inhibits leukemia and lymphoma growth in TRAF2DN/Bcl2 transgenic } \\
\text { model of CLL and SBL }\end{array}$ & 5,10 or $20 \mathrm{mg} / \mathrm{kg}$, i.p.; $21-25$ days & {$[66]$} \\
\hline Dicyano-CDDO & Inhibits UV-irradiated skin tumor in SKH1 hairless mice & $10 \mathrm{nM}$, topically; Twice/week for 17 weeks & [123] \\
\hline $\begin{array}{l}\text { Furoxan- and glycosyl- } \\
\text { based OA }\end{array}$ & Inhibits SMMC-7721 HCC tumors in mice & 12.5 or $25 \mathrm{mg} / \mathrm{kg}$. i.p.; 3 times/week for 21 days & {$[53,54]$} \\
\hline $\begin{array}{l}\mathrm{O}(2) \text {-glyco-sylated diaz- } \\
\quad \text { eniumdiolate-based } \mathrm{OA}\end{array}$ & Inhibits SMMC-7721 HCC tumor in mice & $3 \mathrm{mg} / \mathrm{kg}$, i.v.; 3 times/week for 3 weeks & {$[55]$} \\
\hline PABA/NO-based OA & Inhibits $\mathrm{H} 22$ solid tumors in mice & 10,20 or $40 \mathrm{mg} / \mathrm{kg} /$ day, i.p; 14 days & {$[59]$} \\
\hline AMR-Me & $\begin{array}{l}\text { Inhibits DMBA-induced breast tumors in rats and interferes with Wnt/ } \\
\beta \text {-catenin and NF- } \kappa B \text { signaling }\end{array}$ & $\begin{array}{l}0.8,1.2 \text { or } 1.6 \mathrm{mg} / \mathrm{kg} \text {, oral; } 3 \text { times } / \text { week for } \\
18 \text { weeks }\end{array}$ & [109-111] \\
\hline Dextrose OA & Suppresses LM8 osteosarcoma growth and lung metastasis in mice & 25,50 or $100 \mathrm{mg} / \mathrm{kg}$ i.p.; 4 weeks & [86] \\
\hline
\end{tabular}

\subsection{Pancreatic carcinoma}

In xenograft models of pancreatic cancer, oral administration of CDDO-Me $(7.5 \mathrm{mg} / \mathrm{kg})$ daily for 4 weeks significantly decreased tumor volume and the expression of VEGF, cyclin D1 and survivin [93]. In addition to their efficacy in various xenograft models, OA derivatives also significantly delayed tumor development in transgenic models. In a transgenic mouse model of pancreatic cancer with mutations (LSL-Kras ${ }^{\mathrm{G} 12 \mathrm{D} /+}$, LSL-Trp53 ${ }^{\mathrm{R} 127 \mathrm{H} /+}$, Pdx-1-Cre) $[\mathrm{KPC}]$ synthetic OA derivatives increased survival of KPC mice by 3-4 weeks. In this particular experiment, mice were fed powdered control diet or a diet containing the triterpenoids, CDDO-Me (60 mg/kg diet) or CDDO-EA (400 mg/kg diet) or their respective combinations [23].

\subsection{Lung carcinoma}

OA derivatives are also potent inhibitors of lung carcinogenesis. When mixed in diet and fed to $\mathrm{A} / \mathrm{J}$ mice one week after initiation with vinyl carbamate, CDDO-Me, CDDO-EA and CDDO-MA signifi- cantly decreased lung adenocarcinoma tumor burden by $86-96 \%$, compared to controls [124].

\subsection{Osteosarcoma}

Synthetic OA derivative, dextrose-OA, dose-dependently inhibited LM8 osteosarcoma growth in vivo [86]. Dextrose-OA (25, 50 and $100 \mathrm{mg} / \mathrm{kg}$ body weight) was intraperitoneally administered for 4 weeks. At the end of the 4-week treatment, dextrose-OA significantly inhibited the growth of tumor compared to vehicle control and inhibited metastasis of LM8 osteosarcoma tumor cells to lungs [86].

\section{Clinical trials of synthetic $O A$ derivatives}

CDDO, a multifunctional molecule with apoptosis-inducing activity in cancer cells, was evaluated in a phase 1 clinical trial conducted by Speranza et al. [125]. In this clinical study, seven patients were enrolled for phase I dose-escalation study to 
determine toxicity, maximum tolerated dose (MTD), and pharmacokinetic profiles of CDDO. Following administration of CDDO as a 5-day continuous infusion every 28 days in patients with advanced cancers, this particular compound showed rapid increase in plasma concentration and achieved steady-state plasma level within $48 \mathrm{~h}$. Bardoxolone methyl, a novel synthetic OA triterpenoid, exhibits potent anti-inflammatory activity and anticancer activity. Hong et al. [126] evaluated the first-in-human phase I clinical trial of bardoxolone methyl in patients with advanced solid tumor and lymphoma to delineate the dose-limiting toxicities, MTD, and to characterize its pharmacokinetic and pharmacodynamics parameters. Bardoxolone methyl was administered orally once a day for 21 days and showed a MTD of $900 \mathrm{mg} / \mathrm{d}$ associated with the anti-tumor activity [126]. In an earlier dose escalation study with bardoxolone methyl in 34 or 47 patients with advanced refractory lymphoid solid tumors, bardoxolone methyl was administered orally for 21 days at doses ranging from $5 \mathrm{mg} /$ day or $1.3 \mathrm{~g} /$ day and modulated NF- $\kappa$ B, STAT3 and Nrf2 targets in these tumors. Bardoxolone methyl was well tolerated in $91 \%$ of patients and showed minimal toxicity when administered for up to 1 year in a phase 3 trial [16]. In all clinical trials, bardoxolone methyl was relatively safe [127].

\section{Preclinical and clinical pharmacokinetic studies of $O A$ and its synthetic derivatives}

A highly sensitive HPLC-ES-MS-MS method was developed by Song et al. [128] to determine the bioavailability of OA in healthy Chinese male volunteers. Following administration of oral OA capsules ( $40 \mathrm{mg} /$ volunteer, single dose) to 18 male volunteers, the mean values of $C_{\max }, T_{\max }, \mathrm{AUC}_{0-48}, \mathrm{AUC}_{0 \text {-infinity, }} t_{1 / 2}, \mathrm{CL} / \mathrm{F}$, and $\mathrm{V} / \mathrm{F}$ were found to be $12.12 \pm 6.84 \mathrm{ng} / \mathrm{ml}, \quad 5.2 \pm 2.9 \mathrm{~h}$, $114.34 \pm 74.87 \mathrm{ng} \mathrm{h} / \mathrm{ml}, \quad 124.29 \pm 106.77 \mathrm{ng} \mathrm{h} / \mathrm{ml}, \quad 8.73 \pm 6.11 \mathrm{~h}$, $555.3 \pm 347.7 \mathrm{l} / \mathrm{h}$, and $3371.1 \pm 1990.1 \mathrm{l}$, respectively [128]. In another study, OA (0.5\%) mixed in diet was fed to C57BL/6 mice for 8 weeks and evaluated for its bioavailability, tissue distribution, and its antioxidant activity. Results from this study showed that OA was easily detected by HPLC-MS system and its bioavailability was $0.55 \mu \mathrm{g} / \mathrm{ml}$ in mice plasma, $1.7 \mu \mathrm{g} / \mathrm{g}$ in brain tissue, $4.2 \mu \mathrm{g} / \mathrm{g}$ in heart tissue, $10.3 \mu \mathrm{g} / \mathrm{g}$ in liver tissue, $5.5 \mu \mathrm{g} / \mathrm{g}$ in kidney tissue, $6.0 \mu \mathrm{g} / \mathrm{g}$ in colon tissue and $3.7 \mu \mathrm{g} / \mathrm{g}$ in bladder tissue [129]. The dose-independent pharmacokinetic behavior of OA was investigated after intravenous and oral administration in rats with the doses ranging from $0.5-2$ and $25-50 \mathrm{mg} / \mathrm{kg}$, respectively [130]. Following oral administration, the systemic absorption was extremely low ( $F^{1} / 4$ was $0.7 \%$ ). The low oral bioavailability of OA might be due to poor gastrointestinal absorption and subsequent hepatic first-pass metabolism [15,130]. Different formulations of OA, such as freeze-dried polyvinylpyrrolidone and sodium caprate $\mathrm{OA}$, increased dissolution rate and intestinal permeability when tested in vitro in Caco-2 cells and in vivo in Sprague-Dawley rats, respectively [130,131]. Pharmacokinetic parameters of OA and other pentacyclic triterpene saponins have been reported in detail including the metabolism of OA [132]. Cao et al. [133] synthetized numerous water-soluble amino acid analogues of OA and tested for their bioavailability. Interestingly, aqueous solubility of OA increased from $0.012 \mu \mathrm{g} / \mathrm{ml}$ to $2.5-3.1 \mu \mathrm{g} / \mathrm{ml}$ and absolute oral bioavailability increased 2 -fold $[15,133]$. In a recent study, Cao et al. [134] showed that propylene glycol-linked amino acid/dipeptide diester prodrugs of OA showed better stability, permeability, affinity, and bioavailability. In order to increase OA bioavailability, sucrose-ester stabilized nanosuspension of OA was synthesized and tested in in vitro cancer cell cultures and in vivo in mice [135]. The investigators found that OA nanosuspension bioavailability in A549 human non-small-cell lung cancer cell line was concentration-, temperature- and time-dependent and the formulation showed excellent in vivo oral and intravenous bioavailability in rats [135] and in self-nanoemulsified drug delivery systems [136].

\section{Conclusions and perspectives}

Pentacyclic triterpenoids obtained from natural plant materials have been shown to inhibit tumor cell proliferation, induce apoptosis, increase the life span of tumor-bearing mice compared to control group, as well as prevent angiogenesis, invasion and metastasis of tumor cells to distant organ sites in preclinical models of cancer. They also exhibit multi-functionality by targeting multiple tumor cell promoting extracellular and intracellular protein targets and are thus named multifunctional compounds. In this review, we have highlighted the significance of both natural and synthetic OA derivatives in various organ-based tumor models and discussed the potential of these compounds in chemoprevention and therapy. We have also summarized the reported chemopreventive and therapeutic efficacy of pentacyclic triterpene OA in transgenic, orthotopic and xenograft tumor models. Indications from both in vitro and in vivo studies suggest that OA can indeed suppress multiple molecular targets that play a fundamental role in both development and progression of chronic inflammation and cancer. In this decade alone, several synthetic OA derivatives were synthesized that exhibited potent antitumor activity both in in vitro and in vivo studies with phase- 1 and phase- 2 clinical trials reported for bardoxolone methyl. Bardoxolone methyl seems promising with a good safety profile in human clinical trials. The evidence also supports the similarity of inhibiting common molecular targets in addition to the novel target proteins that play a pivotal role in tumor progression. Using several sensitive instruments, OA absorption, distribution, metabolism and excretion profiles have been reported. OA is bioavailable following oral administration in mice and human pharmacokinetic and pharmacodynamics profiles of $\mathrm{OA}$ and its synthetic derivatives are also discussed. All these studies uphold the traditional use of $\mathrm{OA}$ as well as its usefulness in modern day traditional Chinese medicine clinics. Additional clinical trials are warranted to bring these exciting molecules to clinical use for the benefit of mankind.

\section{Conflict of Interest}

None declared.

\section{Acknowledgments}

This research work was supported by grants from the Singapore Ministry of Health's National Medical Research Council to GS under its Individual Research Grants Funding scheme. APK was supported by grants from Singapore Ministry of Education Tier 2 [MOE2012T2-2-139], Academic Research Fund Tier 1 [R-184-000-228-112] and Cancer Science Institute of Singapore, Experimental Therapeutics I Program [Grant R-713-001-011-271]. The research on AMRMe and breast cancer prevention as presented here was supported by the award R03CA136014 from the National Cancer Institute/National Institutes of Health to AB. The content of this article is solely the responsibility of the authors and does not necessarily represent the official views of the National Cancer Institute or the National Institutes of Health.

\section{References}

[1] R.A. Hill, J.D. Connolly, Triterpenoids, Nat. Prod. Rep. 30 (2013) 1028-1065.

[2] D.R. Phillips, J.M. Rasbery, B. Bartel, S.P. Matsuda, Biosynthetic diversity in plant triterpene cyclization, Curr. Opin. Plant Biol. 9 (2006) 305-314. 
[3] M.N. Laszczyk, Pentacyclic triterpenes of the lupane, oleanane and ursane group as tools in cancer therapy, Planta Med. 75 (2009) 1549-1560.

[4] M.K. Shanmugam, A.H. Nguyen, A.P. Kumar, B.K. Tan, G. Sethi, Targeted inhibition of tumor proliferation, survival, and metastasis by pentacyclic triterpenoids: potential role in prevention and therapy of cancer, Cancer Lett. 320 (2012) 158-170.

[5] H. Sheng, H. Sun, Synthesis, biology and clinical significance of pentacyclic triterpenes: a multi-target approach to prevention and treatment of metabolic and vascular diseases, Nat. Prod. Rep. 28 (2011) 543-593.

[6] M.K. Shanmugam, X. Dai, A.P. Kumar, B.K. Tan, G. Sethi, A. Bishayee, Ursolic acid in cancer prevention and treatment: molecular targets, pharmacokinetics and clinical studies, Biochem. Pharmacol. 85 (2013) 1579-1587.

[7] V.R. Yadav, S. Prasad, B. Sung, R. Kannappan, B.B. Aggarwal, Targeting inflammatory pathways by triterpenoids for prevention and treatment of cancer, Toxins (Basel) 2 (2010) 2428-2466.

[8] P. Dzubak, M. Hajduch, D. Vydra, A. Hustova, M. Kvasnica, D. Biedermann, L. Markova, M. Urban, J. Sarek, Pharmacological activities of natural triterpenoids and their therapeutic implications, Nat. Prod. Rep. 23 (2006) 394-411.

[9] A. Petronelli, G. Pannitteri, U. Testa, Triterpenoids as new promising anticancer drugs, Anticancer Drugs 20 (2009) 880-892.

[10] J. Liu, Pharmacology of oleanolic acid and ursolic acid, J. Ethnopharmacol. 49 (1995) 57-68.

[11] J. Liu, Oleanolic acid and ursolic acid: research perspectives, J. Ethnopharmacol. 100 (2005) 92-94.

[12] S. Shibata, New natural products and plant drugs with pharmacological and therapeutical activity, in: H. Wagner, P. Wolff, (Eds.), Springer-Verlag, 1977, pp. 177-196.

[13] J.L. Simonsen, W.C.J. Ross, Hydroxy acids, hydroxy lactones, hydroxyaldehydo acids, hydroxyketo acids and the stereochemistry of the triterpenes, in: The Terpenes: The Triterpenes and Their Derivatives, Cambridge University Press, Cambridge, 1957.

[14] M.A. Kubo I, Secreted oleanolic acid on the cuticle Olea europaea (Oleaceae); a chemical barrier to fungal attack, Cell. Mol. Life Sci. 40 (1984) 937-938.

[15] S. Jager, K. Winkler, U. Pfuller, A. Scheffler, Solubility studies of oleanolic acid and betulinic acid in aqueous solutions and plant extracts of Viscum album $\mathrm{L}$, Planta Med. 73 (2007) 157-162.

[16] K.T. Liby, M.B. Sporn, Synthetic oleanane triterpenoids: multifunctional drugs with a broad range of applications for prevention and treatment of chronic disease, Pharmacol. Rev. 64 (2012) 972-1003.

[17] N. Suh, Y. Wang, T. Honda, G.W. Gribble, E. Dmitrovsky, W.F. Hickey, R.A. Maue, A.E. Place, D.M. Porter, M.J. Spinella, C.R. Williams, G. Wu, A.J. Dannenberg, K.C. Flanders, J.J. Letterio, D.J. Mangelsdorf, C.F. Nathan, L. Nguyen, W.W. Porter, R.F. Ren, A.B. Roberts, N.S. Roche, K. Subbaramaiah, M.B. Sporn, A novel synthetic oleanane triterpenoid, 2-cyano-3,12-dioxoolean-1,9dien-28-oic acid, with potent differentiating, antiproliferative, and antiinflammatory activity, Cancer Res. 59 (1999) 336-341.

[18] T. Honda, B.V. Rounds, L. Bore, H.J. Finlay, F.G. Favaloro Jr., N. Suh, Y. Wang, M.B. Sporn, G.W. Gribble, Synthetic oleanane and ursane triterpenoids with modified rings A and C: a series of highly active inhibitors of nitric oxide production in mouse macrophages, J. Med. Chem. 43 (2000) 4233-4246.

[19] D. Chauhan, G. Li, K. Podar, T. Hideshima, R. Shringarpure, L. Catley, C. Mitsiades, N. Munshi, Y.T. Tai, N. Suh, G.W. Gribble, T. Honda, R. Schlossman, P. Richardson, M.B. Sporn, K.C. Anderson, The bortezomib/proteasome inhibitor PS-341 and triterpenoid CDDO-Im induce synergistic anti-multiple myeloma (MM) activity and overcome bortezomib resistance, Blood 103 (2004) 3158-3166.

[20] R.K. Thimmulappa, C. Scollick, K. Traore, M. Yates, M.A. Trush, K.T. Liby, M.B. Sporn, M. Yamamoto, T.W. Kensler, S. Biswal, Nrf2-dependent protection from LPS induced inflammatory response and mortality by CDDOImidazolide, Biochem. Biophys. Res. Commun. 351 (2006) 883-889.

[21] K. Liby, R. Risingsong, D.B. Royce, C.R. Williams, T. Ma, M.M. Yore, M.B. Sporn, Triterpenoids CDDO-methyl ester or CDDO-ethyl amide and rexinoids LG100268 or NRX194204 for prevention and treatment of lung cancer in mice, Cancer Prev. Res. (Phila.) 2 (2009) 1050-1058.

[22] J.J. Auletta, J.L. Alabran, B.G. Kim, C.J. Meyer, J.J. Letterio, The synthetic triterpenoid, CDDO-Me, modulates the proinflammatory response to in vivo lipopolysaccharide challenge, J. Interferon Cytokine Res. 30 (2010) 497-508.

[23] K.T. Liby, D.B. Royce, R. Risingsong, C.R. Williams, A. Maitra, R.H. Hruban, M.B. Sporn, Synthetic triterpenoids prolong survival in a transgenic mouse model of pancreatic cancer, Cancer Prev. Res. (Phila.) 3 (2010) 1427-1434.

[24] A. Bishayee, S. Ahmed, N. Brankov, M. Perloff, Triterpenoids as potential agents for the chemoprevention and therapy of breast cancer, Front. Biosci. (Landmark Ed.) 16 (2011) 980-996.

[25] H.F. Hsu, J.Y. Houng, C.L. Chang, C.C. Wu, F.R. Chang, Y.C. Wu, Antioxidant activity, cytotoxicity, and DNA information of Glossogyne tenuifolia, J. Agric. Food Chem. 53 (2005) 6117-6125.

[26] Y. Allouche, F. Warleta, M. Campos, C. Sanchez-Quesada, M. Uceda, G. Beltran, J.J. Gaforio, Antioxidant, antiproliferative, and pro-apoptotic capacities of pentacyclic triterpenes found in the skin of olives on MCF-7 human breast cancer cells and their effects on DNA damage, J. Agric. Food Chem. 59 (2011) $121-130$.

[27] G. Gu, I. Barone, L. Gelsomino, C. Giordano, D. Bonofiglio, G. Statti, F. Menichini, S. Catalano, S. Ando, Oldenlandia diffusa extracts exert antiproliferative and apoptotic effects on human breast cancer cells through ERalpha/Sp1-mediated p53 activation, J. Cell. Physiol. 227 (2012) 3363-3372.

[28] M. Fukumura, H. Ando, Y. Hirai, K. Toriizuka, Y. Ida, Y. Kuchino, Achyranthoside $\mathrm{H}$ methyl ester, a novel oleanolic acid saponin derivative from Achyranthes fauriei roots, induces apoptosis in human breast cancer MCF-7 and MDA-MB-453 cells via a caspase activation pathway, J. Nat. Med. 63 (2009) 181-188.

[29] M. Konopleva, W. Zhang, Y.X. Shi, T. McQueen, T. Tsao, M. Abdelrahim, M.F. Munsell, M. Johansen, D. Yu, T. Madden, S.H. Safe, M.C. Hung, M. Andreeff, Synthetic triterpenoid 2-cyano-3,12-dioxooleana-1,9-dien-28-oic acid induces growth arrest in HER2-overexpressing breast cancer cells, Mol. Cancer Ther. 5 (2006) 317-328.

[30] X. Ling, M. Konopleva, Z. Zeng, V. Ruvolo, L.C. Stephens, W. Schober, T. McQueen, M. Dietrich, T.L. Madden, M. Andreeff, The novel triterpenoid C-28 methyl ester of 2-cyano-3, 12-dioxoolen-1, 9-dien-28-oic acid inhibits metastatic murine breast tumor growth through inactivation of STAT3 signaling, Cancer Res. 67 (2007) 4210-4218.

[31] M.L. Hyer, R. Croxton, M. Krajewska, S. Krajewski, C.L. Kress, M. Lu, N. Suh, M.B. Sporn, V.L. Cryns, J.M. Zapata, J.C. Reed, Synthetic triterpenoids cooperate with tumor necrosis factor-related apoptosis-inducing ligand to induce apoptosis of breast cancer cells, Cancer Res. 65 (2005) 4799-4808.

[32] E.H. Kim, C.X. Deng, M.B. Sporn, K.T. Liby, CDDO-imidazolide induces DNA damage, G2/M arrest and apoptosis in BRCA1-mutated breast cancer cells, Cancer Prev. Res. (Phila.) 4 (2011) 425-434.

[33] J.Y. So, J.E. Wahler, T. Yoon, A.K. Smolarek, Y. Lin, W.J. Shih, H. Maehr, M. Uskokovic, K.T. Liby, M.B. Sporn, N. Suh, Oral administration of a Gemini vitamin D analog, a synthetic triterpenoid and the combination prevents mammary tumorigenesis driven by ErbB2 overexpression, Cancer Prev. Res. (Phila.) 6 (2013) 959-970.

[34] J. Yang, D. Liao, C. Chen, Y. Liu, T.H. Chuang, R. Xiang, D. Markowitz, R.A. Reisfeld, Y. Luo, Tumor-associated macrophages regulate murine breast cancer stem cells through a novel paracrine EGFR/Stat3/Sox-2 signaling pathway, Stem cells 31 (2013) 248-258.

[35] R. Ahmad, D. Raina, C. Meyer, D. Kufe, Triterpenoid CDDO-methyl ester inhibits the Janus-activated kinase-1 (JAK1)signal transducer and activator of transcription-3 (STAT3) pathway by direct inhibition of JAK1 and STAT3, Cancer Res. 68 (2008) 2920-2926.

[36] R. Martin, J. Carvalho-Tavares, E. Ibeas, M. Hernandez, V. Ruiz-Gutierrez, M.L. Nieto, Acidic triterpenes compromise growth and survival of astrocytoma cell lines by regulating reactive oxygen species accumulation, Cancer Res. 67 (2007) 3741-3751.

[37] Y. Fujiwara, Y. Komohara, R. Kudo, K. Tsurushima, K. Ohnishi, T. Ikeda, M. Takeya, Oleanolic acid inhibits macrophage differentiation into the M2 phenotype and glioblastoma cell proliferation by suppressing the activation of STAT3, Oncol. Rep. 26 (2011) 1533-1537.

[38] X. Gao, D. Deeb, H. Jiang, Y. Liu, S.A. Dulchavsky, S.C. Gautam, Synthetic triterpenoids inhibit growth and induce apoptosis in human glioblastoma and neuroblastoma cells through inhibition of prosurvival Akt, NF-kappaB and Notch1 signaling, J. Neurooncol. 84 (2007) 147-157.

[39] J.L. Alabran, A. Cheuk, K. Liby, M. Sporn, J. Khan, J. Letterio, K.S. Leskov, Human neuroblastoma cells rapidly enter cell cycle arrest and apoptosis following exposure to C-28 derivatives of the synthetic triterpenoid CDDO, Cancer Biol. Ther. 7 (2008) 709-717.

[40] K.H. Yoo, J.H. Park, E.J. Cui, K.I. Kim, J.Y. Kim, J. Kim, S.G. Hong, N.I. Baek, I.S Chung, 3-O-acetyloleanolic acid induces apoptosis in human colon carcinoma HCT-116 cells, Phytother. Res. 26 (2012) 1541-1546.

[41] S.A. Reisman, L.M. Aleksunes, C.D. Klaassen, Oleanolic acid activates Nrf2 and protects from acetaminophen hepatotoxicity via Nrf2-dependent and Nrf2independent processes, Biochem. Pharmacol. 77 (2009) 1273-1282.

[42] X. Wang, X.L. Ye, R. Liu, H.L. Chen, H. Bai, X. Liang, X.D. Zhang, Z. Wang, W.L. Li, C.X. Hai, Antioxidant activities of oleanolic acid in vitro: possible role of $\mathrm{Nrf} 2$ and MAP kinases, Chem. Biol. Interact. 184 (2010) 328-337.

[43] J.D. Hayes, M. McMahon, S. Chowdhry, A.T. Dinkova-Kostova, Cancer chemoprevention mechanisms mediated through the Keap1-Nrf2 pathway, Antioxid. Redox Signal. 13 (2010) 1713-1748.

[44] R.J. Thoppil, A. Bishayee, Terpenoids as potential chemopreventive and therapeutic agents in liver cancer, World J. Hepatol. 3 (2011) 228-249.

[45] C.D. Klaassen, S.A. Reisman, Nrf2 the rescue: effects of the antioxidative electrophilic response on the liver, Toxicol. Appl. Pharmacol. 244 (2010) 5765.

[46] J. Liu, Q. Wu, Y.F. Lu, J. Pi, New insights into generalized hepatoprotective effects of oleanolic acid: key roles of metallothionein and Nrf2 induction, Biochem. Pharmacol. 76 (2008) 922-928.

[47] A.L. Eggler, K.A. Gay, A.D. Mesecar, Molecular mechanisms of natural products in chemoprevention: induction of cytoprotective enzymes by Nrf2, Mol. Nutr. Food Res. 52 (Suppl. 1) (2008) S84-S94.

[48] M. Ananthanarayanan, N. Balasubramanian, M. Makishima, D.J. Mangelsdorf, F.J. Suchy, Human bile salt export pump promoter is transactivated by the farnesoid X receptor/bile acid receptor, J. Biol. Chem. 276 (2001) 2885728865.

[49] W. Liu, C. Wong, Oleanolic acid is a selective farnesoid X receptor modulator, Phytother. Res. 24 (2010) 369-373.

[50] X. Wang, H. Bai, X. Zhang, J. Liu, P. Cao, N. Liao, W. Zhang, Z. Wang, C. Hai, Inhibitory effect of oleanolic acid on hepatocellular carcinoma via ERK-p53mediated cell cycle arrest and mitochondrial-dependent apoptosis, Carcinogenesis 34 (2013) 1323-1330. 
[51] M.H. Shyu, T.C. Kao, G.C. Yen, Oleanolic acid and ursolic acid induce apoptosis in HuH7 human hepatocellular carcinoma cells through a mitochondrialdependent pathway and downregulation of XIAP, J. Agric. Food Chem. 58 (2010) 6110-6118.

[52] L. Chen, Y. Zhang, X. Kong, E. Lan, Z. Huang, S. Peng, D.L. Kaufman, J. Tian, Design, synthesis, and antihepatocellular carcinoma activity of nitric oxide releasing derivatives of oleanolic acid, J. Med. Chem. 51 (2008) 4834-4838.

[53] Z. Huang, Y. Zhang, L. Zhao, Y. Jing, Y. Lai, L. Zhang, Q. Guo, S. Yuan, J. Zhang, L. Chen, S. Peng, J. Tian, Synthesis and anti-human hepatocellular carcinoma activity of new nitric oxide-releasing glycosyl derivatives of oleanolic acid, Org. Biomol. Chem. 8 (2010) 632-639.

[54] J. Zhang, Y. Gao, F. Su, Z. Gong, Y. Zhang, Interaction characteristics with bovine serum albumin and retarded nitric oxide release of ZCVI(4)-2, a new nitric oxide-releasing derivative of oleanolic acid, Chem. Pharm. Bull. (Tokyo) 59 (2011) 734-741.

[55] Z. Huang, J. Fu, L. Liu, Y. Sun, Y. Lai, H. Ji, E.E. Knaus, J. Tian, Y. Zhang, Glycosylated diazeniumdiolate-based oleanolic acid derivatives: synthesis, in vitro and in vivo biological evaluation as anti-human hepatocellular carcinoma agents, Org. Biomol. Chem. 10 (2012) 3882-3891.

[56] J. Fu, L. Liu, Z. Huang, Y. Lai, H. Ji, S. Peng, J. Tian, Y. Zhang, Hybrid molecule from 02-(2,4-dinitrophenyl)diazeniumdiolate and oleanolic acid: a glutathione S-transferase pi-activated nitric oxide prodrug with selective anti-human hepatocellular carcinoma activity and improved stability, J. Med. Chem. 56 (2013) 4641-4655.

[57] U.V. Mallavadhani, A. Mahapatra, B. Pattnaik, N. Vanga, N. Suri, A.K. Saxena, Synthesis and anti-cancer activity of some novel C-17 analogs of ursolic and oleanolic acids, Med. Chem. Res. 22 (2013) 1263-1269.

[58] X. Kang, J. Hu, Z.B. Gao, Y. Ju, C.L. Xu, Synthesis, anti-proliferative and proapoptotic activity of novel oleanolic acid azaheterocyclic derivatives, Med. Chem. Comm. 3 (2012) 1245-1249.

[59] L. Liu, J. Fu, T. Li, R. Cui, J. Ling, X. Yu, H. Ji, Y. Zhang, NG, a novel PABA/NObased oleanolic acid derivative, induces human hepatoma cell apoptosis via a ROS/MAPK-dependent mitochondrial pathway, Eur. J. Pharmacol. 691 (2012) $61-68$.

[60] L. Chen, J.B. Wu, F. Lei, S. Qian, L. Hai, Y. Wu, Synthesis and biological evaluation of oleanolic acid derivatives as antitumor agents, J. Asian Nat. Prod. Res. 14 (2012) 355-363.

[61] P. Zhang, H. Li, D. Chen, J. Ni, Y. Kang, S. Wang, Oleanolic acid induces apoptosis in human leukemia cells through caspase activation and poly(ADPribose) polymerase cleavage, Acta Biochim. Biophys. Sin. (Shanghai) 39 (2007) 803-809.

[62] Y.P. Ng, Y. Chen, Y. Hu, F.C. Ip, N.Y. Ip, Olean-12-eno[2,3-c] [1,2,5]oxadiazol28-oic acid (OEOA) induces G1 cell cycle arrest and differentiation in human leukemia cell lines, PLoS ONE 8 (2013) e63580.

[63] V.M. Moreira, J.A. Salvador, S. Simoes, F. Destro, R. Gavioli, Novel oleanolic vinyl boronates: synthesis and antitumor activity, Eur. J. Med. Chem. 63 (2013) 46-56.

[64] Y. Ito, P. Pandey, A. Place, M.B. Sporn, G.W. Gribble, T. Honda, S. Kharbanda, D. Kufe, The novel triterpenoid 2-cyano-3,12-dioxoolean-1,9-dien-28-oic acid induces apoptosis of human myeloid leukemia cells by a caspase-8dependent mechanism, Cell Growth Differ. 11 (2000) 261-267.

[65] G. Kong, D. Wang, H. Wang, J. Wu, J. Bielawski, M. Konopleva, M. Andreeff, P.P. Ruvolo, B.J. Maurer, Synthetic triterpenoids have cytotoxicity in pediatric acute lymphoblastic leukemia cell lines but cytotoxicity is independent of induced ceramide increase in MOLT-4 cells, Leukemia 22 (2008) 1258-1262.

[66] C.L. Kress, M. Konopleva, V. Martinez-Garcia, M. Krajewska, S. Lefebvre, M.L. Hyer, T. McQueen, M. Andreeff, J.C. Reed, J.M. Zapata, Triterpenoids display single agent anti-tumor activity in a transgenic mouse model of chronic lymphocytic leukemia and small B cell lymphoma, PLoS ONE 2 (2007) e559.

[67] P.S. Brookes, K. Morse, D. Ray, A. Tompkins, S.M. Young, S. Hilchey, S. Salim, M. Konopleva, M. Andreeff, R. Phipps, S.H. Bernstein, The triterpenoid 2 cyano-3,12-dioxooleana-1,9-dien-28-oic acid and its derivatives elicit human lymphoid cell apoptosis through a novel pathway involving the unregulated mitochondrial permeability transition pore, Cancer Res. 67 (2007) 17931802.

[68] D.M. Ray, K.M. Morse, S.P. Hilchey, T.M. Garcia, R.E. Felgar, S.B. Maggirwar R.P. Phipps, S.H. Bernstein, The novel triterpenoid 2-cyano-3,12-dioxooleana1,9-dien-28-oic acid (CDDO) induces apoptosis of human diffuse large B-cel lymphoma cells through a peroxisome proliferator-activated receptor gamma-independent pathway, Exp. Hematol. 34 (2006) 1202-1211.

[69] S.H. Bernstein, S. Venkatesh, M. Li, J. Lee, B. Lu, S.P. Hilchey, K.M. Morse, H.M Metcalfe, J. Skalska, M. Andreeff, P.S. Brookes, C.K. Suzuki, The mitochondrial ATP-dependent Lon protease: a novel target in lymphoma death mediated by the synthetic triterpenoid CDDO and its derivatives, Blood 119 (2012) 33213329.

[70] S. Shishodia, G. Sethi, M. Konopleva, M. Andreeff, B.B. Aggarwal, A synthetic triterpenoid, CDDO-Me, inhibits IkappaBalpha kinase and enhances apoptosis induced by TNF and chemotherapeutic agents through down-regulation of expression of nuclear factor kappaB-regulated gene products in human leukemic cells, Clin. Cancer Res. 12 (2006) 1828-1838.

[71] R. Ahmad, D. Raina, C. Meyer, S. Kharbanda, D. Kufe, Triterpenoid CDDO-Me blocks the NF-kappaB pathway by direct inhibition of IKKbeta on Cys-179, J. Biol. Chem. 281 (2006) 35764-35769.

[72] R. Ahmad, S. Liu, E. Weisberg, E. Nelson, I. Galinsky, C. Meyer, D. Kufe, S. Kharbanda, R. Stone, Combining the FLT3 inhibitor PKC412 and the triterpenoid CDDO-Me synergistically induces apoptosis in acute myeloid leukemia with the internal tandem duplication mutation, Mol. Cancer Res. 8 (2010) 986-993.

[73] T. Ikeda, M. Sporn, T. Honda, G.W. Gribble, D. Kufe, The novel triterpenoid CDDO and its derivatives induce apoptosis by disruption of intracellular redox balance, Cancer Res. 63 (2003) 5551-5558.

[74] I. Samudio, S. Kurinna, P. Ruvolo, B. Korchin, H. Kantarjian, M. Beran, K. Dunner Jr., S. Kondo, M. Andreeff, M. Konopleva, Inhibition of mitochondrial metabolism by methyl-2-cyano-3,12-dioxooleana-1,9-diene-28-oate induces apoptotic or autophagic cell death in chronic myeloid leukemia cells, Mol. Cancer Ther. 7 (2008) 1130-1139.

[75] K. Liby, T. Hock, M.M. Yore, N. Suh, A.E. Place, R. Risingsong, C.R. Williams, D.B. Royce, T. Honda, Y. Honda, G.W. Gribble, N. Hill-Kapturczak, A. Agarwal, M.B. Sporn, The synthetic triterpenoids, CDDO and CDDO-imidazolide, are potent inducers of heme oxygenase-1 and Nrf2/ARE signaling, Cancer Res. 65 (2005) 4789-4798.

[76] K.A. Lucio, G. Rocha Gda, L.C. Moncao-Ribeiro, J. Fernandes, C.M. Takiya, C.R. Gattass, Oleanolic acid initiates apoptosis in non-small cell lung cancer cell lines and reduces metastasis of a B16F10 melanoma model in vivo, PLoS One 6 (2011) e28596.

[77] J.Z. Shan, Y.Y. Xuan, S.Q. Ruan, M. Sun, Proliferation-inhibiting and apoptosisinducing effects of ursolic acid and oleanolic acid on multi-drug resistance cancer cells in vitro, Chin. J. Integrat. Med. 17 (2011) 607-611.

[78] J. Wang, M. Yu, L. Xiao, S. Xu, Q. Yi, W. Jin, Radiosensitizing effect of oleanolic acid on tumor cells through the inhibition of GSH synthesis in vitro, Oncol. Rep. 30 (2013) 917-924.

[79] I. Samudio, M. Konopleva, H. Pelicano, P. Huang O. Frolova, W. Bornmann, Y. Ying, R. Evans, R. Contractor, M. Andreeff, A novel mechanism of action of methyl-2-cyano-3,12 dioxoolean-1,9 diene-28-oate: direct permeabilization of the inner mitochondrial membrane to inhibit electron transport and induce apoptosis, Mol. Pharmacol. 69 (2006) 1182-1193.

[80] W. Zou, S. Chen, X. Liu, P. Yue, M.B. Sporn, F.R. Khuri, S.Y. Sun, C-FLIP downregulation contributes to apoptosis induction by the novel synthetic triterpenoid methyl-2-cyano-3, 12-dioxooleana-1, 9-dien-28-oate (CDDOMe) in human lung cancer cells, Cancer Biol. Ther. 6 (2007) 1614-1620.

[81] W. Zou, X. Liu, P. Yue, Z. Zhou, M.B. Sporn, R. Lotan, F.R. Khuri, S.Y. Sun, C-Jun $\mathrm{NH} 2$-terminal kinase-mediated up-regulation of death receptor 5 contributes to induction of apoptosis by the novel synthetic triterpenoid methyl-2cyano-3,12-dioxooleana-1, 9-dien-28-oate in human lung cancer cells, Cancer Res. 64 (2004) 7570-7578.

[82] B. Melichar, M. Konopleva, W. Hu, K. Melicharova, M. Andreeff, R.S. Freedman, Growth-inhibitory effect of a novel synthetic triterpenoid, 2-cyano-3,12dioxoolean-1,9-dien-28-oic acid, on ovarian carcinoma cell lines not dependent on peroxisome proliferator-activated receptor-gamma expression, Gynecol. Oncol 93 (2004) 149-154.

[83] Z. Duan, R.Y. Ames, M. Ryan, F.J. Hornicek, H. Mankin, M.V. Seiden, CDDO-Me, a synthetic triterpenoid, inhibits expression of IL-6 and Stat3 phosphorylation in multi-drug resistant ovarian cancer cells, Cancer Chemother. Pharmacol. 63 (2009) 681-689.

[84] X. Gao, Y. Liu, D. Deeb, A.S. Arbab, A.M. Guo, S.A. Dulchavsky, S.C. Gautam, Synthetic oleanane triterpenoid, CDDO-Me, induces apoptosis in ovarian cancer cells by inhibiting prosurvival AKT/NF-kappaB/mTOR signaling, Anticancer Res. 31 (2011) 3673-3681.

[85] X. Gao, Y. Liu, D. Deeb, P. Liu, A. Liu, A.S. Arbab, S.C. Gautam, ROS mediate proapoptotic and antisurvival activity of oleanane triterpenoid CDDO-Me in ovarian cancer cells, Anticancer Res. 33 (2013) 215-221.

[86] Y. Hua, Z. Zhang, J. Li, Q. Li, S. Hu, M. Sun, Z. Cai, Oleanolic acid derivative DexOA has potent anti-tumor and anti-metastatic activity on osteosarcoma cells in vitro and in vivo, Invest. New Drugs 29 (2011) 258-265.

[87] J. Wei, M. Liu, H. Liu, H. Wang, F. Wang, Y. Zhang, L. Han, X. Lin, Oleanolic acid arrests cell cycle and induces apoptosis via ROS-mediated mitochondrial depolarization and lysosomal membrane permeabilization in human pancreatic cancer cells, J. Appl. Toxicol. 33 (2013) 756-765.

[88] J. Wei, H. Liu, M. Liu, N. Wu, J. Zhao, L. Xiao, L. Han, E. Chu, X. Lin, Oleanolic acid potentiates the antitumor activity of 5-fluorouracil in pancreatic cancer cells, Oncol. Rep. 28 (2012) 1339-1345.

[89] D. Deeb, X. Gao, A.S. Arbab, K. Barton, S.A. Dulchavsky, S.C. Gautam, CDDOMe: a novel synthetic triterpenoid for the treatment of pancreatic cancer, Cancers (Basel) 2 (2010) 1779-1793.

[90] D. Deeb, X. Gao, Y. Liu, S.H. Kim, K.R. Pindolia, A.S. Arbab, S.C. Gautam, Inhibition of cell proliferation and induction of apoptosis by oleanane triterpenoid (CDDO-Me) in pancreatic cancer cells is associated with the suppression of hTERT gene expression and its telomerase activity, Biochem. Biophys. Res. Commun. 422 (2012) 561-567.

[91] D. Deeb, X. Gao, Y. Liu, N.R. Varma, A.S. Arbab, S.C. Gautam, Inhibition of telomerase activity by oleanane triterpenoid CDDO-Me in pancreatic cancer cells is ROS-dependent, Molecules 18 (2013) 3250-3265.

[92] I. Samudio, M. Konopleva, N. Hail Jr., Y.X. Shi, T. McQueen, T. Hsu, R. Evans, T. Honda, G.W. Gribble, M. Sporn, H.F. Gilbert, S. Safe, M. Andreeff, 2-Cyano3,12-dioxooleana-1,9-dien-28-imidazolide (CDDO-Im) directly targets mitochondrial glutathione to induce apoptosis in pancreatic cancer, J. Biol. Chem. 280 (2005) 36273-36282.

[93] I. Jutooru, G. Chadalapaka, M. Abdelrahim, M.R. Basha, I. Samudio, M. Konopleva, M. Andreeff, S. Safe, Methyl 2-cyano-3,12-dioxooleana-1,9-dien28-oate decreases specificity protein transcription factors and inhibits pancreatic tumor growth: role of microRNA-27a, Mol. Pharmacol. 78 (2010) $226-236$. 
[94] A.S. Leal, R. Wang, J.A. Salvador, Y. Jing, Synthesis of novel heterocyclic oleanolic acid derivatives with improved antiproliferative activity in solid tumor cells, Org. Biomol. Chem. 11 (2013) 1726-1738.

[95] M.L. Hyer, R. Shi, M. Krajewska, C. Meyer, I.V. Lebedeva, P.B. Fisher, J.C. Reed, Apoptotic activity and mechanism of 2-cyano-3,12-dioxoolean-1,9-dien-28oic-acid and related synthetic triterpenoids in prostate cancer, Cancer Res. 68 (2008) 2927-2933.

[96] Y. Liu, X. Gao, D. Deeb, S.C. Gautam, Oleanane triterpenoid CDDO-Me inhibits Akt activity without affecting PDK1 kinase or PP2A phosphatase activity in cancer cells, Biochem. Biophys. Res. Commun. 417 (2012) 570-575.

[97] Y. Liu, X. Gao, D. Deeb, A.S. Arbab, S.C. Gautam, Telomerase reverse transcriptase (TERT) is a therapeutic target of oleanane triterpenoid CDDOMe in prostate cancer, Molecules 17 (2012) 14795-14809.

[98] J. Hao, J. Liu, X. Wen, H. Sun, Synthesis and cytotoxicity evaluation of oleanolic acid derivatives, Bioorg. Med. Chem. Lett. 23 (2013) 2074-2077.

[99] D. Deeb, X. Gao, H. Jiang, S.A. Dulchavsky, S.C. Gautam, Oleanane triterpenoid CDDO-Me inhibits growth and induces apoptosis in prostate cancer cells by independently targeting pro-survival Akt and mTOR, Prostate 69 (2009) 851860.

[100] D. Deeb, X. Gao, H. Jiang, B. Janic, A.S. Arbab, Y. Rojanasakul, S.A. Dulchavsky, S.C. Gautam, Oleanane triterpenoid CDDO-Me inhibits growth and induces apoptosis in prostate cancer cells through a ROS-dependent mechanism, Biochem. Pharmacol. 79 (2010) 350-360.

[101] K. Hata, K. Hori, S. Takahashi, Differentiation- and apoptosis-inducing activities by pentacyclic triterpenes on a mouse melanoma cell line, J. Nat. Prod. 65 (2002) 645-648.

[102] Q. Liu, H. Liu, L. Zhang, T. Guo, P. Wang, M. Geng, Y. Li, Synthesis and antitumor activities of naturally occurring oleanolic acid triterpenoid saponins and their derivatives, Eur. J. Med. Chem. 64 (2013) 1-15.

[103] N. Hail Jr., M. Konopleva, M. Sporn, R. Lotan, M. Andreeff, Evidence supporting a role for calcium in apoptosis induction by the synthetic triterpenoid 2cyano-3,12-dioxooleana-1,9-dien-28-oic acid (CDDO), J. Biol. Chem. 279 (2004) 11179-11187.

[104] T. Ikeda, Y. Nakata, F. Kimura, K. Sato, K. Anderson, K. Motoyoshi, M. Sporn, D. Kufe, Induction of redox imbalance and apoptosis in multiple myeloma cells by the novel triterpenoid 2-cyano-3,12-dioxoolean-1,9-dien-28-oic acid, Mol. Cancer Ther. 3 (2004) 39-45.

[105] K. Liby, N. Voong, C.R. Williams, R. Risingsong, D.B. Royce, T. Honda, G.W. Gribble, M.B. Sporn, J.J. Letterio, The synthetic triterpenoid CDDO-Imidazolide suppresses STAT phosphorylation and induces apoptosis in myeloma and lung cancer cells, Clin. Cancer Res. 12 (2006) 4288-4293.

[106] E.L. Abel, J.D. Bubel, M.S. Simper, L. Powell, S.A. McClellan, M. Andreeff, M.C. MacLeod, J. DiGiovanni, Protection against 2-chloroethyl ethyl sulfide (CEES)induced cytotoxicity in human keratinocytes by an inducer of the glutathione detoxification pathway, Toxicol. Appl. Pharmacol. 255 (2011) 176-183.

[107] G.B. Singh, S. Singh, S. Bani, B.D. Gupta, S.K. Banerjee, Anti-inflammatory activity of oleanolic acid in rats and mice, J. Pharm. Pharmacol. 44 (1992) 456-458.

[108] J.L. Townson, I.C. Macdonald, K.T. Liby, L. Mackenzie, D.W. Dales, B.D. Hedley, P.J. Foster, M.B. Sporn, A.F. Chambers, The synthetic triterpenoid CDDOImidazolide suppresses experimental liver metastasis, Clin. Exp. Metastasis 28 (2011) 309-317.

[109] A. Bishayee, A. Mandal, R.J. Thoppil, A.S. Darvesh, D. Bhatia, Chemopreventive effect of a novel oleanane triterpenoid in a chemically induced rodent model of breast cancer, Int. J. Cancer 133 (2013) 1054-1063.

[110] A. Mandal, D. Bhatia, A. Bishayee, Simultaneous disruption of estrogen receptor and Wnt/beta-catenin signaling is involved in methyl amooraninmediated chemoprevention of mammary gland carcinogenesis in rats, Mol. Cell. Biochem. 384 (2013) 239-250.

[111] A. Mandal, D. Bhatia, A. Bishayee, Suppression of inflammatory cascade is implicated in methyl amooranin-mediated inhibition of experimental mammary carcinogenesis, Mol. Carcinog. (2013).

[112] D. Liao, Z. Liu, W.J. Wrasidlo, Y. Luo, G. Nguyen, T. Chen, R. Xiang, R.A. Reisfeld, Targeted therapeutic remodeling of the tumor microenvironment improves an HER-2 DNA vaccine and prevents recurrence in a murine breast cancer model, Cancer Res. 71 (2011) 5688-5696.

[113] K. Liby, R. Risingsong, D.B. Royce, C.R. Williams, M.M. Yore, T. Honda, G.W. Gribble, W.W. Lamph, N. Vannini, I. Sogno, A. Albini, M.B. Sporn, Prevention and treatment of experimental estrogen receptor-negative mammary carcinogenesis by the synthetic triterpenoid CDDO-methyl ester and the rexinoid LG100268, Clin. Cancer Res. 14 (2008) 4556-4563.

[114] E.H. Kim, C. Deng, M.B. Sporn, D.B. Royce, R. Risingsong, C.R. Williams, K.T. Liby, CDDO-methyl ester delays breast cancer development in BRCA1mutated mice, Cancer Prev. Res. (Phila.) 5 (2012) 89-97.

[115] H. Lapillonne, M. Konopleva, T. Tsao, D. Gold, T. McQueen, R.L. Sutherland, T. Madden, M. Andreeff, Activation of peroxisome proliferator-activated receptor gamma by a novel synthetic triterpenoid 2-cyano-3,12dioxooleana-1,9-dien-28-oic acid induces growth arrest and apoptosis in breast cancer cells, Cancer Res. 63 (2003) 5926-5939.

[116] K. Tran, R. Risingsong, D. Royce, C.R. Williams, M.B. Sporn, K. Liby, The synthetic triterpenoid CDDO-methyl ester delays estrogen receptor-negative mammary carcinogenesis in polyoma middle $\mathrm{T}$ mice, Cancer Prev. Res. (Phila.) 5 (2012) 726-734.

[117] R.A. Furtado, E.P. Rodrigues, F.R. Araujo, W.L. Oliveira, M.A. Furtado, M.B. Castro, W.R. Cunha, D.C. Tavares, Ursolic acid and oleanolic acid suppress preneoplastic lesions induced by 1,2-dimethylhydrazine in rat colon, Toxicol. Pathol. 36 (2008) 576-580.

[118] N.B. Janakiram, C. Indranie, S.V. Malisetty, P. Jagan, V.E. Steele, C.V. Rao Chemoprevention of colon carcinogenesis by oleanolic acid and its analog in male F344 rats and modulation of COX-2 and apoptosis in human colon HT29 cancer cells, Pharm. Res. 25 (2008) 2151-2157.

[119] X. Gao, D. Deeb, Y. Liu, A.S. Arbab, G.W. Divine, S.A. Dulchavsky, S.C. Gautam, Prevention of prostate cancer with oleanane synthetic triterpenoid CDDO-Me in the TRAMP mouse model of prostate cancer, Cancers (Basel) 3 (2011) 3353-3369.

[120] A.E. Place, N. Suh, C.R. Williams, R. Risingsong, T. Honda, Y. Honda, G.W Gribble, L.M. Leesnitzer, J.B. Stimmel, T.M. Willson, E. Rosen, M.B. Sporn, The novel synthetic triterpenoid, CDDO-imidazolide, inhibits inflammatory response and tumor growth in vivo, Clin. Cancer Res. 9 (2003) 2798-2806.

[121] Y. Tabe, M. Konopleva, Y. Kondo, R. Contractor, T. Tsao, S. Konoplev, Y. Shi, X Ling, J.C. Watt, Y. Tsutsumi-Ishii, A. Ohsaka, I. Nagaoka, J.P. Issa, S.C. Kogan, M. Andreeff, PPARgamma-active triterpenoid CDDO enhances ATRA-induced differentiation in APL, Cancer Biol. Ther. 6 (2007) 1967-1977.

[122] T. Oguro, J. Liu, C.D. Klaassen, T. Yoshida, Inhibitory effect of oleanolic acid on 12-O-tetradecanoylphorbol-13-acetate-induced gene expression in mouse skin, Toxicol. Sci. 45 (1998) 88-93.

[123] A.T. Dinkova-Kostova, S.N. Jenkins, S.L. Wehage, D.L. Huso, A.L. Benedict, K.K. Stephenson, J.W. Fahey, H. Liu, K.T. Liby, T. Honda, G.W. Gribble, M.B. Sporn, P. Talalay, A dicyanotriterpenoid induces cytoprotective enzymes and reduces multiplicity of skin tumors in UV-irradiated mice, Biochem. Biophys. Res. Commun. 367 (2008) 859-865.

[124] K. Liby, D.B. Royce, C.R. Williams, R. Risingsong, M.M. Yore, T. Honda, G.W Gribble, E. Dmitrovsky, T.A. Sporn, M.B. Sporn, The synthetic triterpenoids CDDO-methyl ester and CDDO-ethyl amide prevent lung cancer induced by vinyl carbamate in A/J mice, Cancer Res. 67 (2007) 2414-2419.

[125] G. Speranza, M.E. Gutierrez, S. Kummar, J.M. Strong, R.J. Parker, J. Collins, Y. Yu, L. Cao, A.J. Murgo, J.H. Doroshow, A. Chen, Phase I study of the synthetic triterpenoid, 2-cyano-3, 12-dioxoolean-1, 9-dien-28-oic acid (CDDO), in advanced solid tumors, Cancer Chemother. Pharmacol. 69 (2012) 431-438.

[126] D.S. Hong, R. Kurzrock, J.G. Supko, X. He, A. Naing, J. Wheler, D. Lawrence, J.P. Eder, C.J. Meyer, D.A. Ferguson, J. Mier, M. Konopleva, S. Konoplev, M. Andreeff, D. Kufe, H. Lazarus, G.I. Shapiro, B.J. Dezube, A phase I first-inhuman trial of bardoxolone methyl in patients with advanced solid tumors and lymphomas, Clin. Cancer Res. 18 (2012) 3396-3406.

[127] P.E. Pergola, P. Raskin, R.D. Toto, C.J. Meyer, J.W. Huff, E.B. Grossman, M. Krauth, S. Ruiz, P. Audhya, H. Christ-Schmidt, J. Wittes, D.G. Warnock, Bardoxolone methyl and kidney function in CKD with type 2 diabetes, $\mathrm{N}$. Engl. J. Med. 365 (2011) 327-336.

[128] M. Song, T.J. Hang, Y. Wang, L. Jiang, X.L. Wu, Z. Zhang, J. Shen, Y. Zhang, Determination of oleanolic acid in human plasma and study of its pharmacokinetics in Chinese healthy male volunteers by HPLC tandem mass spectrometry, J. Pharm. Biomed. Anal. 40 (2006) 190-196.

[129] M.C. Yin, M.C. Lin, M.C. Mong, C.Y. Lin, Bioavailability, distribution, and antioxidative effects of selected triterpenes in mice, J. Agric. Food Chem. 60 (2012) 7697-7701.

[130] D.W. Jeong, Y.H. Kim, H.H. Kim, H.Y. Ji, S.D. Yoo, W.R. Choi, S.M. Lee, C.K. Han, H.S. Lee, Dose-linear pharmacokinetics of oleanolic acid after intravenous and oral administration in rats, Biopharm. Drug Dispos. 28 (2007) 51-57.

[131] H.H. Tong, Z. Du, G.N. Wang, H.M. Chan, Q. Chang, L.C. Lai, A.H. Chow, Y. Zheng, Spray freeze drying with polyvinylpyrrolidone and sodium caprate for improved dissolution and oral bioavailability of oleanolic acid, a BCS Class IV compound, Int. J. Pharm. 404 (2011) 148-158.

[132] S. Gao, S. Basu, Z. Yang, A. Deb, M. Hu, Bioavailability challenges associated with development of saponins as therapeutic and chemopreventive agents, Curr. Drug Targets 13 (2012) 1885-1899.

[133] F. Cao, J. Jia, Z. Yin, Y. Gao, L. Sha, Y. Lai, O. Ping, Y. Zhang, Ethylene glycollinked amino acid diester prodrugs of oleanolic acid for pepT1-mediated transport: synthesis, intestinal permeability and pharmacokinetics, Mol. Pharm. (2012).

[134] F. Cao, Y. Gao, M. Wang, L. Fang, Q. Ping, Propylene glycol-linked amino acid/ dipeptide diester prodrugs of oleanolic acid for PepT1-mediated transport: synthesis, intestinal permeability, and pharmacokinetics, Mol. Pharm. 10 (2013) 1378-1387.

[135] W. Li, S. Das, K.Y. Ng, P.W. Heng, Formulation, biological and pharmacokinetic studies of sucrose ester-stabilized nanosuspensions of oleanolic acid, Pharm. Res. 28 (2011) 2020-2033.

[136] J. Xi, Q. Chang, C.K. Chan, Z.Y. Meng, G.N. Wang, J.B. Sun, Y.T. Wang, H.H. Tong Y. Zheng, Formulation development and bioavailability evaluation of a selfnanoemulsified drug delivery system of oleanolic acid, AAPS Pharm. Sci. Tech. 10 (2009) 172-182. 